\title{
Strategic Petroleum Reserve Annual Report
}

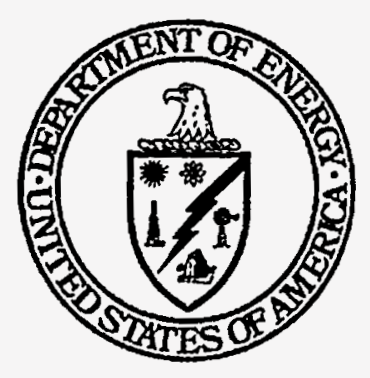

February 15, 1996

\section{U.S. Department of Energy}

Assistant Secretary for Fossil Energy Office of Strategic Petroleum Reserve

Washington, DC 20585
MSTRIBUTION OF THIS DOCUMENT IS UNLIMITED 
This report has been reproduced directly from the best available copy.

Available to DOE and DOE contractors from the Office of Scientific and Technical Information, P.O. Box 62, Oak Ridge, TN 37831; prices available from (615) 576-8401.

Available to the public from the U.S. Department of Commerce, Technology Administration, National Technical Information Service, Springfield, VA 22161.

(703) $487-4650$.

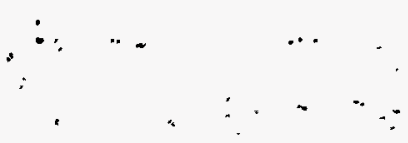




\section{TABLE OF CONTENTS}

EXECUTIVE SUMMARY $\ldots \ldots \ldots \ldots \ldots \ldots \ldots \ldots \ldots \ldots \ldots \ldots \ldots \ldots \ldots \ldots$

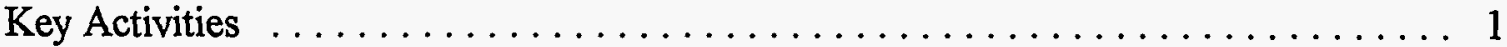

1996 Activities . . . . . . . . . . . . . . . . . . . . . . . . . . 2

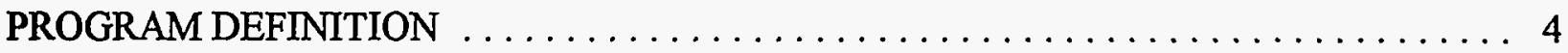

Mission ....................................... 4

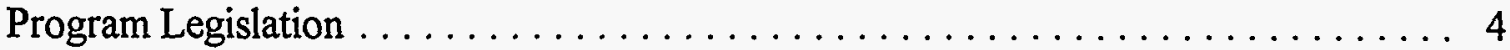

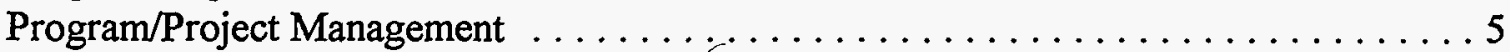

STORAGE FACILITY DEVELOPMENT PROGRAM $\ldots \ldots \ldots \ldots \ldots \ldots \ldots$

Development of the $750-$ Million Barrel Storage Program . . . . . . . . . . . . . 6

Storage Facilities Status . . . . . . . . . . . . . . . . . . . . . . . 6

Storage Facilities Life Extension Program $\ldots \ldots \ldots \ldots \ldots \ldots \ldots \ldots \ldots \ldots$

OIL ACQUISITION AND FILL, CALENDAR YEAR $1995 \ldots \ldots \ldots \ldots \ldots \ldots \ldots$

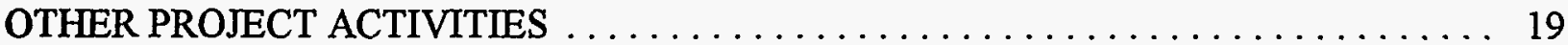

Oil Stabilization Program ............................ 19

Commercialization of SPR Distribution Facilities . . . . . . . . . . . . . . . . 19

Procurement and Contractor Support . . . . . . . . . . . . . . . . . . 21

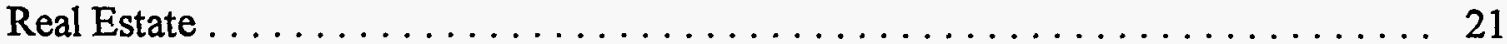

Security $\ldots \ldots \ldots \ldots \ldots \ldots \ldots \ldots \ldots \ldots \ldots \ldots \ldots \ldots \ldots \ldots \ldots \ldots \ldots \ldots \ldots, 22$

ENVIRONMENT, SAFETY AND HEALTH $\ldots \ldots \ldots \ldots \ldots \ldots \ldots \ldots \ldots \ldots \ldots$

Environmental Compliance ............................ 23

Other Environmental, Safety and Health Actions $\ldots \ldots \ldots \ldots \ldots \ldots \ldots \ldots 24$

BUDGET AND FINANCE 25

Major Budget and Financing Actions During $1995 \ldots \ldots \ldots \ldots \ldots \ldots \ldots \ldots$

Appropriations . . . . . . . . . . . . . . . . . . . . . . . . . 26

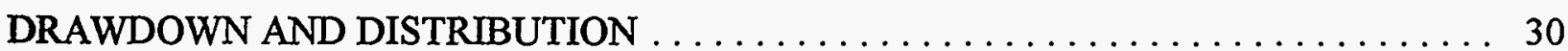

Distribution Plan ................................... 30

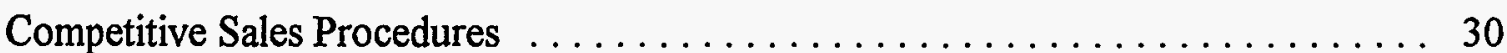

Drawdown and Distribution Capabilities . . . . . . . . . . . . . . . . . . 31

1995 Drawdown Readiness Activities . . . . . . . . . . . . . . . . . . . . . . . . . . 36

CUSTOMER SERVICE TO THE NATION AND U.S. REFINERS $\ldots \ldots \ldots \ldots \ldots \ldots . \ldots 7$

CONTINUOUS QUALITY IMPROVEMENT . . . . . . . . . . . . . . . . . . . . 39 
APPENDIX A Strategic Petroleum Reserve Site Status $\ldots \ldots \ldots \ldots \ldots \ldots \ldots \ldots \ldots \ldots$ APPENDIX B Strategic Petroleum Reserve Crude Oil Specifications . . . . . . . . 55 


\section{LIST OF TABLES}

Page

TABLE 1 Strategic Petroleum Reserve Oil Fill History . . . . . . . . . . . . . . . . . 14

TABLE 2 Crude Oil Received Through $1995 \ldots \ldots \ldots \ldots \ldots \ldots \ldots \ldots \ldots \ldots$

TABLE 3 Strategic Petroleum Reserve Crude Oil Inventory As of December 31, $1995 \ldots \ldots 18$

TABLE 4 Strategic Petroleum Reserve Appropriations . . . . . . . . . . . . . . . . . 29

TABLE 5 Strategic Petroleum Reserve Crude Oil Streams . . . . . . . . . . . . . . . 33

TABLE 6 Current Drawdown and Distribution Capabilities .............. 34 


\section{LIST OF FIGURES}

Page

FIGURE 1 Strategic Petroleum Reserve Complexes and Associated Pipelines and

Terminals . . . . . . . . . . . . . . . . . . . . . . 7

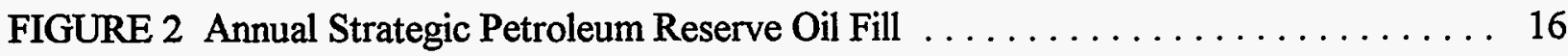

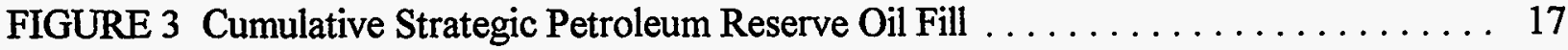

FIGURE 4 Strategic Petroleum Reserve Annual Funding . . . . . . . . . . . . . . 27

FIGURE 5 Strategic Petroleum Reserve Cumulative Funding . . . . . . . . . . . 28

FIGURE 6 Strategic Petroleum Reserve Drawdown/Distribution Capability . . . . . . . . 35

FIGURE 7 Strategic Petroleum Reserve Pipeline and Marine Distribution Capabilities . . . . 38 


\section{EXECUTIVE SUMMARY}

Section 165 of the Energy Policy and Conservation Act (Public Law 94-163), as amended, requires the Secretary of Energy to submit annual reports to the President and the Congress on activities of the Strategic Petroleum Reserve (SPR). This report describes activities for the year ending December 31, 1995.

\section{KEY ACTIVITIES}

\section{Strategic Petroleum Reserve OIL AcQuisition}

During 1995, there were no increases to the Strategic Petroleum Reserve crude oil inventory due to a lack of funding for additional purchases. As of the end of the year, the Reserve's inventory was 591.6 million barrels.

\section{OIL Stabilization PRogram}

During 1995, the Department continued to correct the Reserve's crude oil inventory problems associated with a higher than normal gas content and elevated temperatures. Heat exchangers were installed at the Bryan Mound, West Hackberry and Bayou Choctaw sites. The Reserve commenced degassing oil at Bryan Mound and West Hackberry. As of December 31, 1995, a total of 30 million barrels had been degassed.

\section{WEEKS ISLAND}

During 1995 the Department pursued a number of activities to implement its 1994 decision to decommission the Weeks Island facility. These activities included mitigation measures to prevent further geological problems and commencement of the relocation of 72 million barrels of crude oil to other Strategic Petroleum Reserve storage facilities. Mitigation measures in 1995 included monitoring of brine accumulation in the mine reservoir, continuous introduction of saturated brine into crevassed areas, and construction of a 60 -foot diameter by 210 -foot deep freeze wall around the sinkhole to control the groundwater inflow during drawdown.

Freeze wall construction, using chilled liquid calcium chloride, was completed in late October 1995, thereby providing for mine structural stability during crude oil relocation to Big Hill and Bayou Choctaw which began on November 8, 1995. Relocation of the crude oil 
inventory, except for approximately 2 million barrels of residual fuel oil, is scheduled to be completed by November 1996. Completion of decommissioning activities, including removal of residual oil, and final closure of the mine storage facility is expected by mid-1999.

\section{Commercialization Of Strategic Petroleum Reserve Distribution Facilities}

In 1995, the Department continued its activities to permit commercial use of Strategic Petroleum Reserve distribution facilities (i.e., the St. James marine terminal and crude oil pipelines). With fill of the Reserve approximately 80 percent complete and drawdown only required in the event of a national energy emergency, these facilities are underutilized. Under the authority granted in the Energy Policy and Conservation Act, the Department issued a solicitation in September 1994 inviting industry to submit offers for the leasing of the Strategic Petroleum Reserve St. James marine terminal. By making this facility available for commercial use, the Department expects to: (1) reduce the operational cost of the Reserve, (2) generate revenue from the Government's investment, and (3) support industry in meeting the Nation's needs for crude oil distribution.

In 1995, after receiving no response to the St. James marine terminal solicitation, the Strategic Petroleum Reserve revised its leasing strategy inviting industry to submit proposed business ventures which would maximize return of revenue while meeting the Strategic Petroleum Reserve's mission requirements. Due to the Weeks Island oil relocation, the St. James solicitation has been rescheduled. However, plans were accelerated to issue a solicitation inviting industry to submit offers by the end of December 1995 to lease the Department-owned pipelines withing the Seaway complex. Award is scheduled for March 31, 1996.

\section{Life Extension Program}

The Life Extension Program was initiated in 1994 to replace or upgrade aging and obsolete Strategic Petroleum Reserve storage facilities and systems. The goal of the Life Extension Program is that by the year 2000, all major systems will have been upgraded or replaced to extend the useful life of the Reserve's facilities and drawdown systems to the year 2025. During 1995 the Strategic Petroleum Reserve completed conceptual designs for the Life Extension Program and awarded contracts for the acquisition of standardized pumps, motors and cavern instrumentation, installation of new distributive control systems, modification of cavern piping configurations and internal lining of two deteriorated brine disposal pipelines.

\section{ACTIVITIES}

During 1996, the Department will be involved in two major activities-the sale of up to seven million barrels of crude oil from the Strategic Petroleum Reserve and an initiative to store foreign-owned oil in the Reserve. On January 26, 1996, the Balanced Budget Downpayment Act 
authorized the sale of up to 7 million barrels of Weeks Island oil to obtain $\$ 100$ million in proceeds to fund the decommissioning of the Weeks Island sites and other Reserve facilities requirements. The Department also has offered to store foreign-owned oil in the underutilized Reserve caverns to generate revenues for the U.S. Treasury and promote global stockpiling. 


\section{PROGRAM DEFINITION}

\section{MISSION}

The Strategic Petroleum Reserve (SPR) is a large crude oil stockpile, under the control of the President of the United States. The Strategic Petroleum Reserve mission is to reduce vulnerability to economic, national security, and foreign policy consequences of supply interruptions by discouraging supply disruptions as a tool of other nations, and by adding to crude oil supplies in the United States, in the event of a disruption due either to political, military, or natural causes. The Strategic Petroleum Reserve is mandated by the Energy Policy and Conservation Act, as amended, and by the comprehensive energy plans of all Administrations since 1975 in recognition of the long term dependence of the United States on imported crude oil and petroleum products.

\section{PROGRAM LEGISLATION}

The Strategic Petroleum Reserve was authorized by Congress with the enactment on December 22, 1975, of the Energy Policy and Conservation Act (Public Law 94-163), which declared it to be United States policy to establish a Strategic Petroleum Reserve of up to one billion barrels of petroleum products to reduce the impact of a severe energy supply interruption and to carry out the obligations of the United States under the International Energy Program.

Section 154 of the Energy Policy and Conservation Act required the preparation of a Strategic Petroleum Reserve Plan. The Plan, addressing the development and implementation of the Strategic Petroleum Reserve, was submitted to the Congress on February 16, 1977, and became effective on April 18, 1977.

Strategic Petroleum Reserve Plan Amendment No. 1 accelerated the planned schedule for filling the Reserve. Amendment No. 2 to the Strategic Petroleum Reserve Plan authorized an increase in the Strategic Petroleum Reserve size from 500 million barrels to one billion barrels. The Amendment described Department of Energy plans to store 750 million barrels of petroleum in underground storage facilities.

On October 31, 1979, the Department of Energy submitted Amendment No. 3, a Distribution Plan for the Strategic Petroleum Reserve, to the Congress. The Distribution Plan described the methods for drawdown and distribution of petroleum from the five existing Strategic Petroleum Reserve storage sites.

On December 1, 1982, the President transmitted Amendment No. 4, a new Drawdown Plan, to the Congress for the use of the Strategic Petroleum Reserve. This Plan, required under 
the Energy Emergency Preparedness Act of 1982, went into effect immediately and provides procedures for the drawdown, sale, and distribution of petroleum from the Strategic Petroleum Reserve. The Drawdown Plan replaces the Distribution Plan established by Amendment No. 3.

The 1990 amendments to the Energy Policy and Conservation Act (Public Law 101-383) required the Department to amend the Strategic Petroleum Reserve Plan to prescribe plans for completion of one billion barrels of storage capacity.

\section{PROGRAM/PROJECT MANAGEMENT}

The Strategic Petroleum Reserve Office was created under the Energy Policy and Conservation Act for the establishment, management, and maintenance of the Strategic Petroleum Reserve. The Assistant Secretary for Fossil Energy has overall programmatic responsibility for achieving the goals and objectives of the Strategic Petroleum Reserve Program. This responsibility has been delegated to the Deputy Assistant Secretary for Strategic Petroleum Reserve, Richard D. Furiga, and is exercised through offices located in Washington, D.C.

The Project Management Office is located in New Orleans, Louisiana, and is under the direction of the Project Manager, William C. Gibson, Jr. It carries out day-to-day project activities, including the management and operation of five oil storage sites and one marine terminal. 


\section{STORAGE FACILITY DEVELOPMENT PROGRAM}

\section{DEVELOPMENT OF THE 750-MILLION BARREL STORAGE PROGRAM}

The Department has developed five large underground crude oil storage facilities in salt domes along the Gulf Coast of Texas and Louisiana to stockpile 750 million barrels of crude oil. The five storage sites, comprising the 750-million barrel program, are Bryan Mound and Big Hill in Texas, and West Hackberry, Bayou Choctaw, and Weeks Island in Louisiana. The five storage sites are grouped into three distribution systems--Seaway, Texoma and Capline. Each distribution system is connected by Department of Energy pipelines to commercial crude oil pipeline networks and to one or more commercial or Government-owned marine terminals. The locations of the current Strategic Petroleum Reserve storage sites and their distribution pipelines and terminals are shown in Figure 1.

During 1995, the Department initiated actions to draw down and decommission the Weeks Island storage facility due to geotechnical problems which pose a significant risk of potential oil loss and environmental damage. This situation is discussed further under the Weeks Island site status. This action will reduce the overall storage capacity of the Reserve from 750 million to 680 million barrels, and the maximum drawdown and distribution rate of the Reserve from 4.5 to 3.9 million barrels per day.

\section{STORAGE FACILITIES STATUS}

\section{BRYAN MOUND}

The Bryan Mound storage facility is located in Brazoria County, Texas, approximately three miles southwest of Freeport. The site has twenty storage caverns with a combined storage capacity of 226 million barrels and an inventory of 217 million barrels. The site is available for both fill and drawdown operations at this time; however, there is a reduction in the crude available for drawdown due to the higher than normal vapor pressure for a portion of the site's inventory.

To resolve the current crude vapor pressure problems at Bryan Mound, the Department has contracted for the degasification of approximately 91 million barrels of Bryan Mound crude oil. Degasification of the crude was started in August 1995 and is scheduled for completion in April 1998. At the end of 1995, approximately 11.4 million barrels (12.5\%) of the affected crude oil were degassed. 
FIGURE 1

STRATEGIC PETROLEUM RESERVE STORAGE SITES AND DISTRBUTION SYSTEM

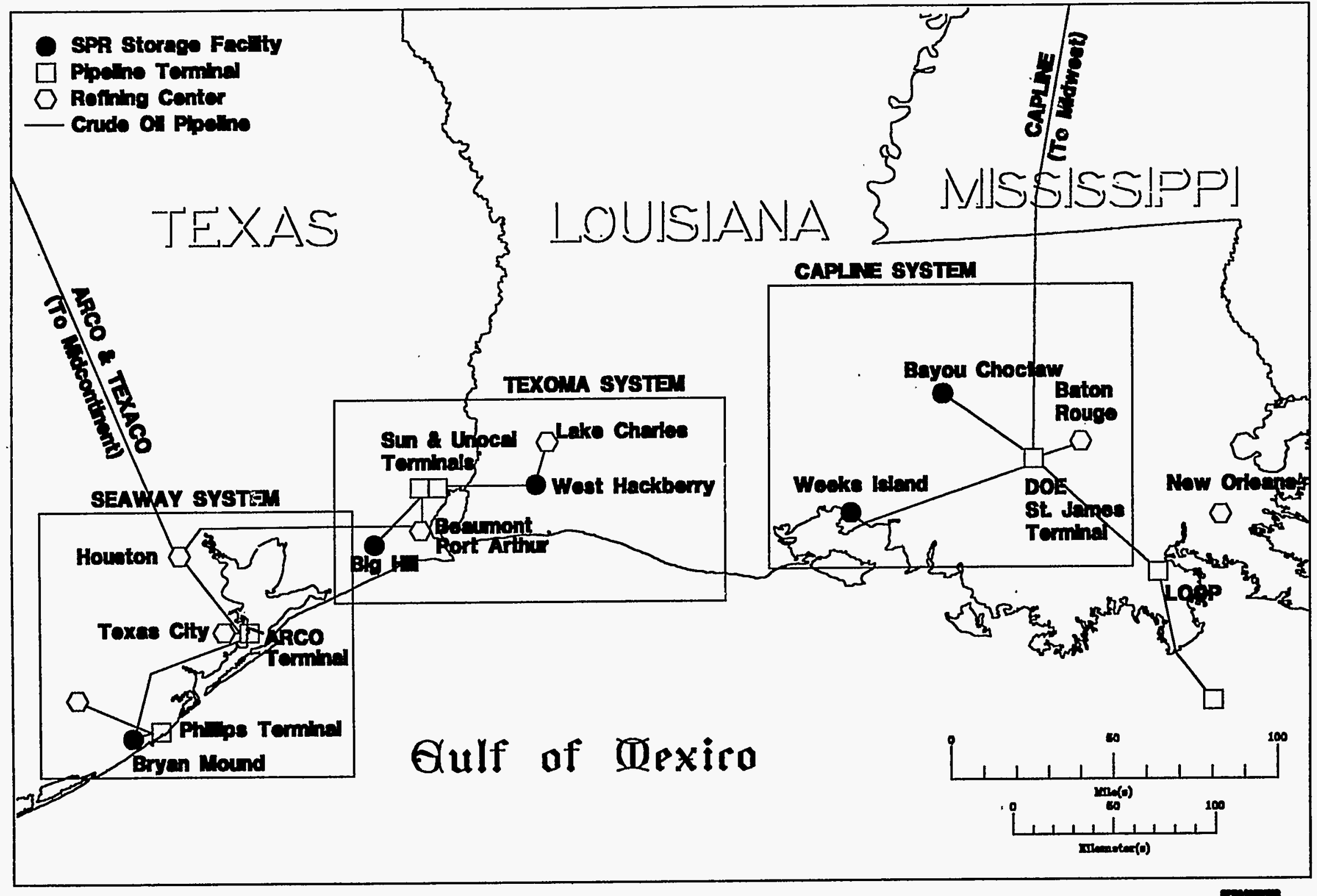


A major project to replace the site's brine disposal pipeline to the Gulf of Mexico which had deteriorated from brine disposal operations during cavern leaching and oil fill was completed and hydro tested, and became fully operational in November 1995.

During 1995, the Department pursued several construction projects in the implementation of the overall Life Extension Program at the Bryan Mound site. In March 1995, the Department completed the installation of the heat exchangers to mitigate geothermal heating of the crude oil. In September, the Department award contracts to acquire new water pumps and motors, install a new distributive control system, and reconfigure the site's pipe racks and cavern piping configurations.

\section{WEST HACKBERRY}

The West Hackberry storage facility is located in Cameron Parish, Louisiana, approximately 22 miles southwest of Lake Charles. The site has 22 storage caverns with a combined storage capacity of 219 million barrels and an inventory of 204 million barrels. The site is available for both fill and drawdown operations.

To resolve the crude vapor pressure problems at West Hackberry, the Department contracted for degasification of approximately 19.1 million barrels of West Hackberry crude oil. Degasification of the crude started in July 1995 and was completed on January 4, 1996.

During 1995, the Department pursued several construction projects in the implementation of the overall Life Extension Program at the West Hackberry site. In March 1995, the Department completed the installation of the heat exchangers to mitigate geothermal heating of the crude oil. The Department completed a contract to install an internal lining in the deteriorated pipeline to the brine disposal wells. In September, the Department awarded contracts to acquire new water pumps and motors, install a new distributive control system, and reconfigure the site's pipe racks and cavern piping configurations.

\section{BAYOU CHOCTAW}

The Bayou Choctaw storage facility is located in Iberville Parish, Louisiana, approximately 12 miles southwest of Baton Rouge. The site has six storage caverns with a combined storage capacity of 75 million barrels. During 1995, the Bayou Choctaw site received 7 million barrels of sour crude oil from Weeks Island, increasing the site's total inventory to 59 million barrels. In order to accommodate the maximum transfer of Weeks Island oil to Bayou Choctaw, the Department converted one of the site's three sweet crude caverns to sour crude service. As a result, the site's sour crude capacity was increased from 38.6 to 51.0 million barrels and the site's sweet crude capacity was decreased from 36.4 to 24.0 million barrels. 
The site is available for drawdown operations; however, there is a reduction in the crude available for drawdown due to the higher than normal vapor pressure of a portion of the site's inventory. To resolve the current crude vapor pressure problems at Bayou Choctaw, the Department's contract for the degasification provides for degasifying approximately 9 million barrels of Bayou Choctaw crude, utilizing the degassification unit from West Hackberry upon completion of operations at that site. Degassification of the affected Bayou Choctaw crude is scheduled to commence in April 1996 and be completed in July 1996.

During 1995, the Department pursued several construction projects in the implementation of the overall Life Extension Program at the Bayou Choctaw site. The Department installed an internal lining in the deteriorated pipeline to the brine disposal wells, and completed a contract to replace deteriorated onsite piping. In addition, the Department initiated the installation and replacement of electrical cable trays and duct banks, and completed the installation of the two heat exchangers in late December 1994 to mitigate geothermal heating of crude oil.

\section{BIG HILl}

The Big Hill storage facility is located in Jefferson County, Texas, 20 miles southwest of Beaumont. The site has 14 storage caverns with a combined storage capacity of 160 million barrels. During 1995, the Big Hill site received 6 million barrels of sour crude from Weeks Island, increasing the site's total inventory to 49 million barrels.

The site is available for drawdown operations; however, there is a reduction in the crude available for drawdown due to the higher than normal vapor pressure of a portion of the site's inventory. To resolve the current crude vapor pressure problems at Big Hill, the Department's contract for the degasification provides for the degasifying of approximately 26 million barrels of Big Hill crude, utilizing the degasification unit from Bayou Choctaw upon completion of operations at that site. Degasification of the affected Big Hill crude is scheduled to commence in August 1996 and be completed in May 1997.

\section{WEEKS ISLAND}

The Weeks Island storage facility is located in Iberia Parish, Louisiana, approximately 95 miles southwest of New Orleans. The Department acquired this storage site in 1977 and converted an existing conventional salt mine to oil storage with a capacity of 70 million barrels. Development and oil fill of this site was completed in 1982.

On December 15, 1994, the Secretary of Energy announced that the Department plans to decommission the Weeks Island storage facility due to geotechnical problems which pose a significant risk to continued use as an oil storage facility, i.e. surface water from above the salt dome is entering the Weeks Island storage chamber. The continuous inflow of subsurface water 
aquifers into the mine continues to pose a high risk for uncontrolled water inflow and the potential displacement of oil to the sediments above the salt, which could cause environmental damage and oil loss.

During 1994 and 1995, the Department undertook a number of mitigative measures to control the water inflow and ensure there is no loss of crude oil or damage to the surrounding ecosystems. Initial measures included the injection of saturated brine within the crevassed area at the top of salt to minimize further leaching of the flow path into the mine and pressurizing the oil storage chamber to slow the inflow rate into the storage chamber. During 1995, the Department initiated the construction of a large freeze wall around the sinkhole as a further precautionary measure. This freeze wall will control ground water access to the sinkhole and prevent water intrusion into the storage chamber during drawdown. The construction of the freeze wall was initiated in June 1995 and completed in October 1995. The freeze wall is a 60 -foot frozen ring of ground surrounding the sinkhole. The freeze wall was constructed by circulating chilled liquid calcium chloride at -35 degrees Fahrenheit through three concentric rings of wells drilled into the top of the salt formation.

On November 8, 1995, the Strategic Petroleum Reserve initiated the drawdown of the Weeks Island mine and relocation of the 72 million barrels of Weeks Island sour crude oil inventory to other Strategic Petroleum Reserve storage sites. Approximately 15.5 million barrels are being transferred to the Bayou Choctaw site via the Reserve's pipeline system and St James Terminal and the balance, excluding that amount which may be sold pursuant to the Balanced Budget Downpayment Act, is being shipped through the Texaco gulf coast pipeline system to the Big Hill site in Texas. As of December 31, 1995, approximately 13 million barrels had been removed from Weeks Island. Of that quantity, 6.7 million barrels had been transferred to Bayou Choctaw, 5.3 million barrels had been delivered to Big Hill and the remainder was in transit. The transfer rate is averaging approximately 235,000 barrels a day and it is expected that the relocation of the Weeks Island inventory, except for a residual amount, will be completed by the end of 1996.

The Department developed plans for decommissioning the Weeks Island site once the oil is removed. To comply with the National Environmental Policy Act (NEPA), the Department has held public hearings and prepared and issued an Environmental Assessment on the proposed decommissioning plans. After the Weeks Island storage chamber is emptied, the Department plans to backfill the mine with saturated brine and recover as much residual crude remaining in the mine as possible through oil skimming methods. Afterwards the mine will be sealed and the site will be decommissioned.

In an effort to minimize the economic impacts on the current employees and the community, the Department held a public meeting in New Iberia, Louisiana, on March 2, 1995, for the purposes of gathering input from members of the community on possible commercial 
uses for the Weeks Island facility. In general, the major interest expressed at this hearing was for salt dome geological research studies. The Department plans to minimize the impacts on the current employees through personnel reassignments, severance benefits and out placement assistance.

\section{STORAGE FACILITIES LIFE EXTENSION PROGRAM}

The Strategic Petroleum Reserve's storage facilities were originally designed for an operational life of 20 years. Construction at four sites, Bryan Mound, West Hackberry, Bayou Choctaw and Weeks Island, was completed in the early 1980s, and most of these systems will reach the end of their design life around the year 2000. Many of the systems and equipment at these sites (i.e., raw water, brine disposal, electrical, instrumentation) are experiencing an increasing number of failures and increasing maintenance costs associated with the later stages of design life.

During 1993, a Life Extension Program was initiated to ensure that the Strategic Petroleum Reserve can continue to meet its mission readiness and system availability, through the year 2025. The goal of the Life Extension Program is that by the year 2000, all major systems will have been upgraded or replaced to extend the useful life of the Reserve's facilities and drawdown systems to the year 2025 .

A Comprehensive Life Extension Plan has been developed, which provides for replacing and modernizing all of the mechanical, civil, electrical and instrumentation systems that are nearing the end of their operational lives. The Comprehensive Life Extension Plan focuses on (a) the simplification of site/system configurations by reducing the numbers of motors, pumps and valves by 30 to 60 percent, (b) improving logistics through standardization of systems and equipment among all of the sites, (c) achieving higher systems availability through the application of more modern, reliable technology, and (d) reducing the annual operating and maintenance cost of facilities by 10 to 20 percent. Following completion of the Comprehensive Life Extension Plan, conceptual designs were developed for the Life Extension Program at each site. Life extension projects previously proposed for Weeks Island and the St. James Terminal have been deleted due to their respective decommissioning and commercialization plans.

During 1995, the Department of Energy awarded contracts totaling over $\$ 77.3$ million towards engineering design, equipment procurement, and site construction in the implementation of the Life Extension Program. Procurement and construction contracts during 1995 include:

- $\quad$ Procurement of standardized pumps, motors, valves and cavern instrumentation for Bryan Mound and West Hackberry.

- $\quad$ Procurement of new flow control valves for the Big Hill site. 
- Installation of a new distributive control system and reconfiguration of cavern piping systems and site pipe racks at Bryan Mound and West Hackberry.

- Internal lining of deteriorated brine disposal pipelines at West Hackberry and Bayou Choctaw.

- Construction of electrical cable trays and duct banks at Bayou Choctaw. 


\section{OIL ACQUISITION AND FILL}

Due to the lack of available funding, there were no Strategic Petroleum Reserve oil acquisition and fill activities during calendar year 1995. As of December 31, 1995, the Reserve's crude oil inventory was 591,640,401 barrels. Projections for fill of the Reserve during 1996 are not included due to the current plans for no oil purchases during that year.

Fiscal and calendar year-end inventories and average daily fill rates since 1977 are presented in Table 1. Strategic Petroleum Reserve crude oil fill is illustrated on both an annual and cumulative basis in Figures 2 and 3, respectively.

Table 2 shows the crude oil quantities received since the inception of the Strategic Petroleum Reserve program through 1995 by country of origin. Of the total oil in storage, 65.7 percent is high sulfur (sour) and 34.3 percent is low sulfur (sweet). Table 3 provides information on the location of this inventory by storage site. The quality specifications used when acquiring Strategic Petroleum Reserve crude oil can be found in Appendix B of this report. 


\section{TABLE 1 \\ Strategic Petroleum Reserve OIL Fill History}

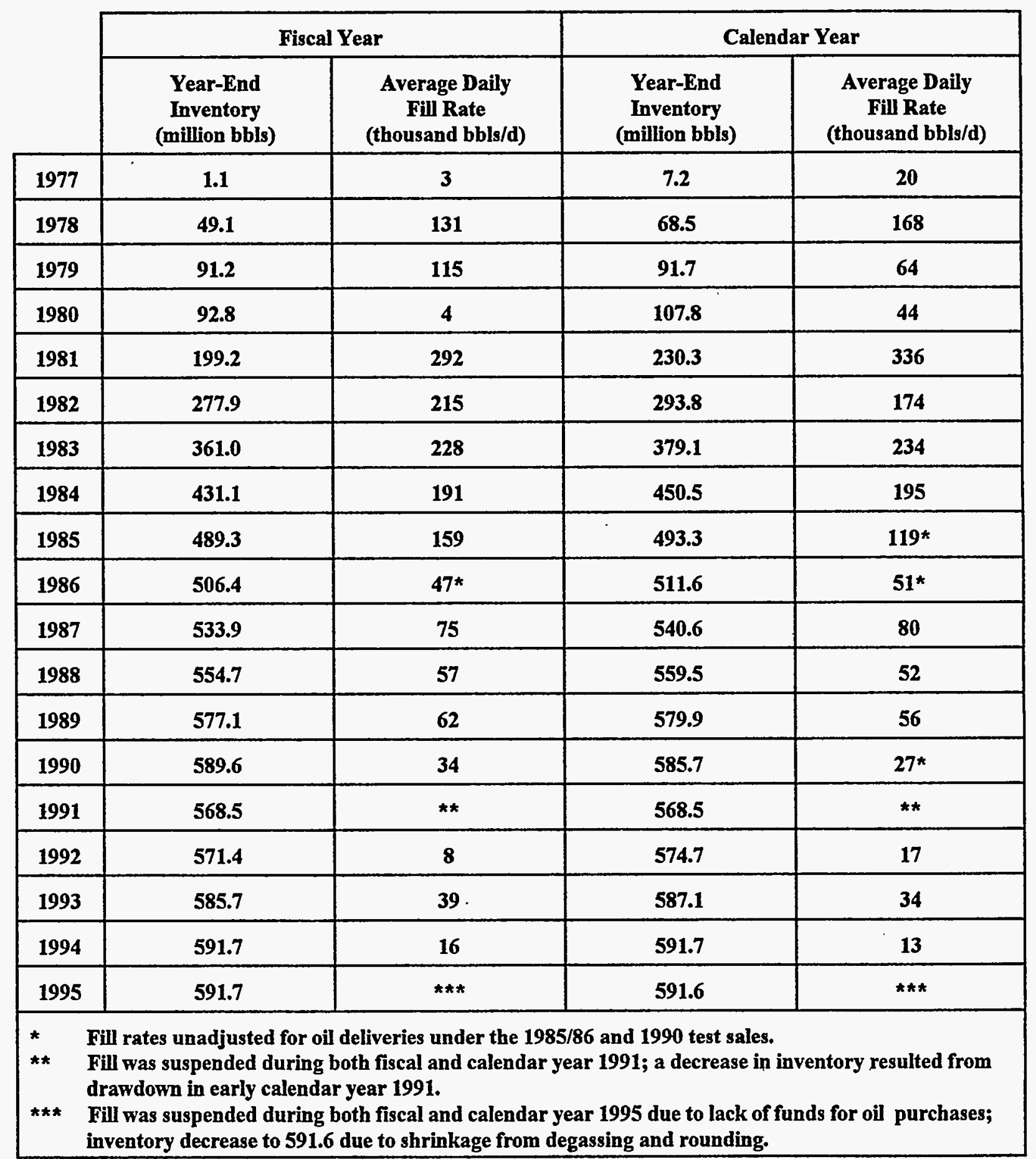




\section{TABLE 2 \\ Crude OL ReceIved Through 1995 (MILLION BARRELS)}

\begin{tabular}{|c|c|c|c|}
\hline Source Country & 1995 & Cumulative & Percent of Total \\
\hline Merico & & 256.7 & 41.9 \\
\hline United Kingdom & & 147.3 & 24.0 \\
\hline $\begin{array}{l}\text { United States: } \\
\text { Alaska } \\
\text { Other* }\end{array}$ & & $\begin{array}{r}48.1 \\
31.4 \\
16.7\end{array}$ & $\begin{array}{r}7.8 \\
5.1 \\
2.7\end{array}$ \\
\hline Saudi Arabia $=$ & & 27.1 & 4.4 \\
\hline Libya & & 23.7 & 3.9 \\
\hline Iran & & 20.0 & 3.3 \\
\hline United Arab Emirates & & 18.4 & 3.0 \\
\hline Nigeria & & 15.1 & 2.5 \\
\hline Norway & & 11.9 & 1.9 \\
\hline Oman & & 9.0 & 1.5 \\
\hline Egypt & & 8.9 & 1.5 \\
\hline Ecuador & & 6.2 & 1.0 \\
\hline Algeria & & 6.2 & 1.0 \\
\hline Cameroon & & 3.4 & 0.6 \\
\hline Iraq & & 3.4 & 0.6 \\
\hline Gabon & & 2.4 & 0.4 \\
\hline Qatar & & 2.3 & 0.4 \\
\hline Angola & & 1.0 & 0.2 \\
\hline Venezuela & & 0.9 & 0.1 \\
\hline Peru & & 0.4 & 0.1 \\
\hline Argentina & & 0.4 & 0.1 \\
\hline TOTAL RECEIPTS** & 0 & 612.8 & 100.0 \\
\hline \multicolumn{4}{|c|}{$\begin{array}{l}\text { * Includes shipments from Naval Petroleum Reserves } \\
\text { ** Unadjusted for deliveries during } 1985 / 1986 \text { and } 1990 \text { test sales and } 1991 \text { drawdown and for operational } \\
\text { gains and losses. }\end{array}$} \\
\hline
\end{tabular}




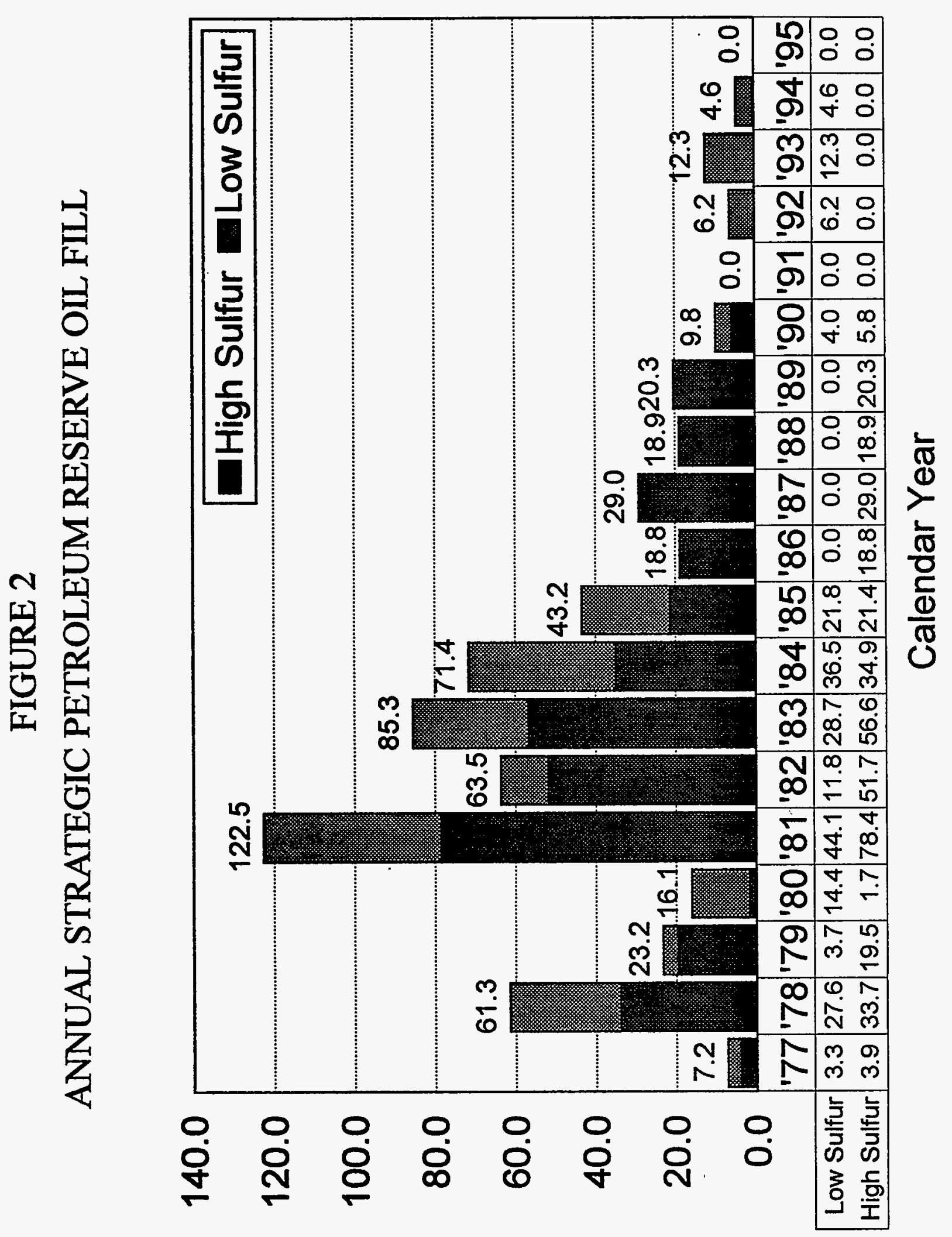

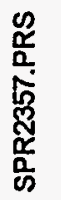

s|əנมе Uo!!|!W 

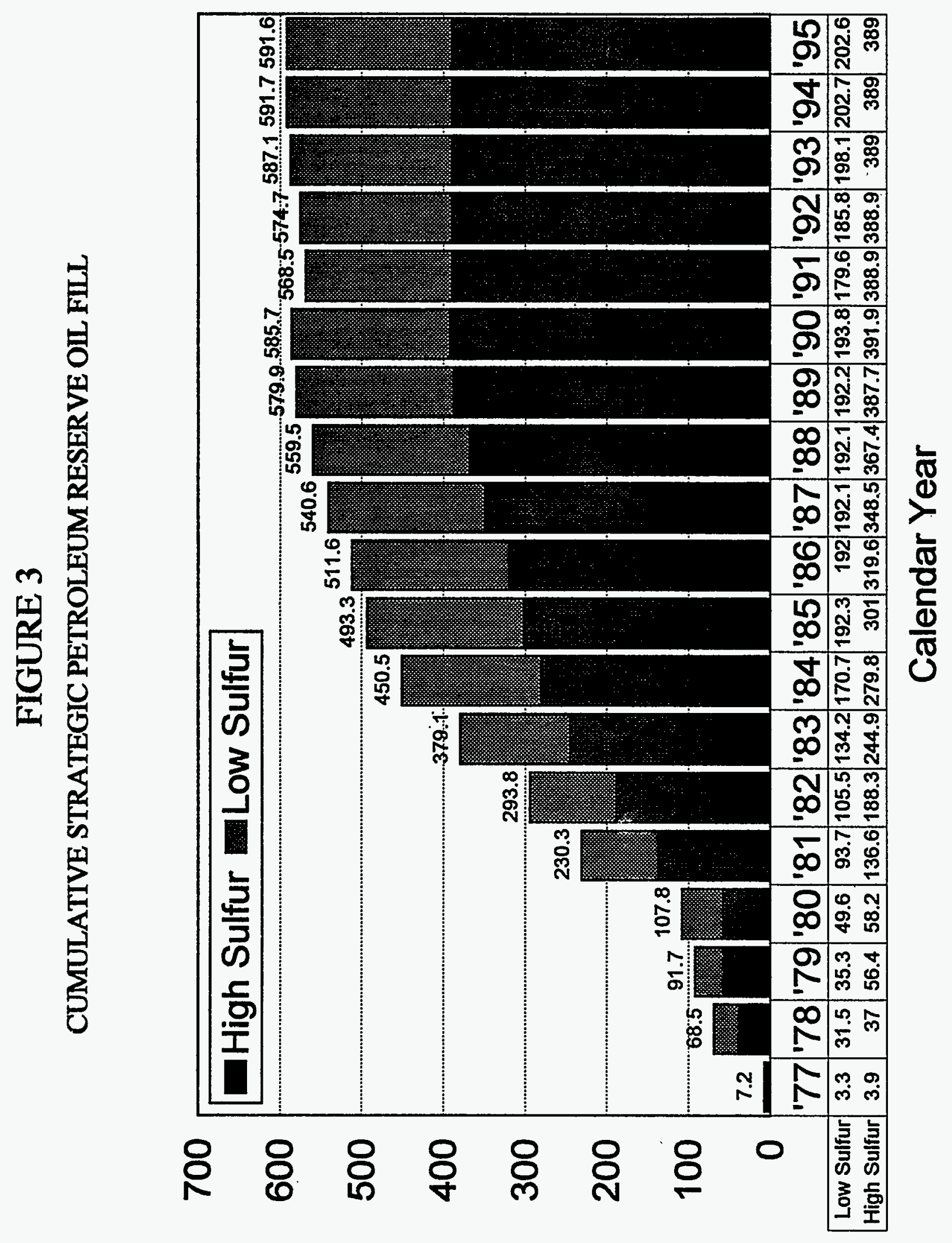

s|əuseg uo!!I!W 


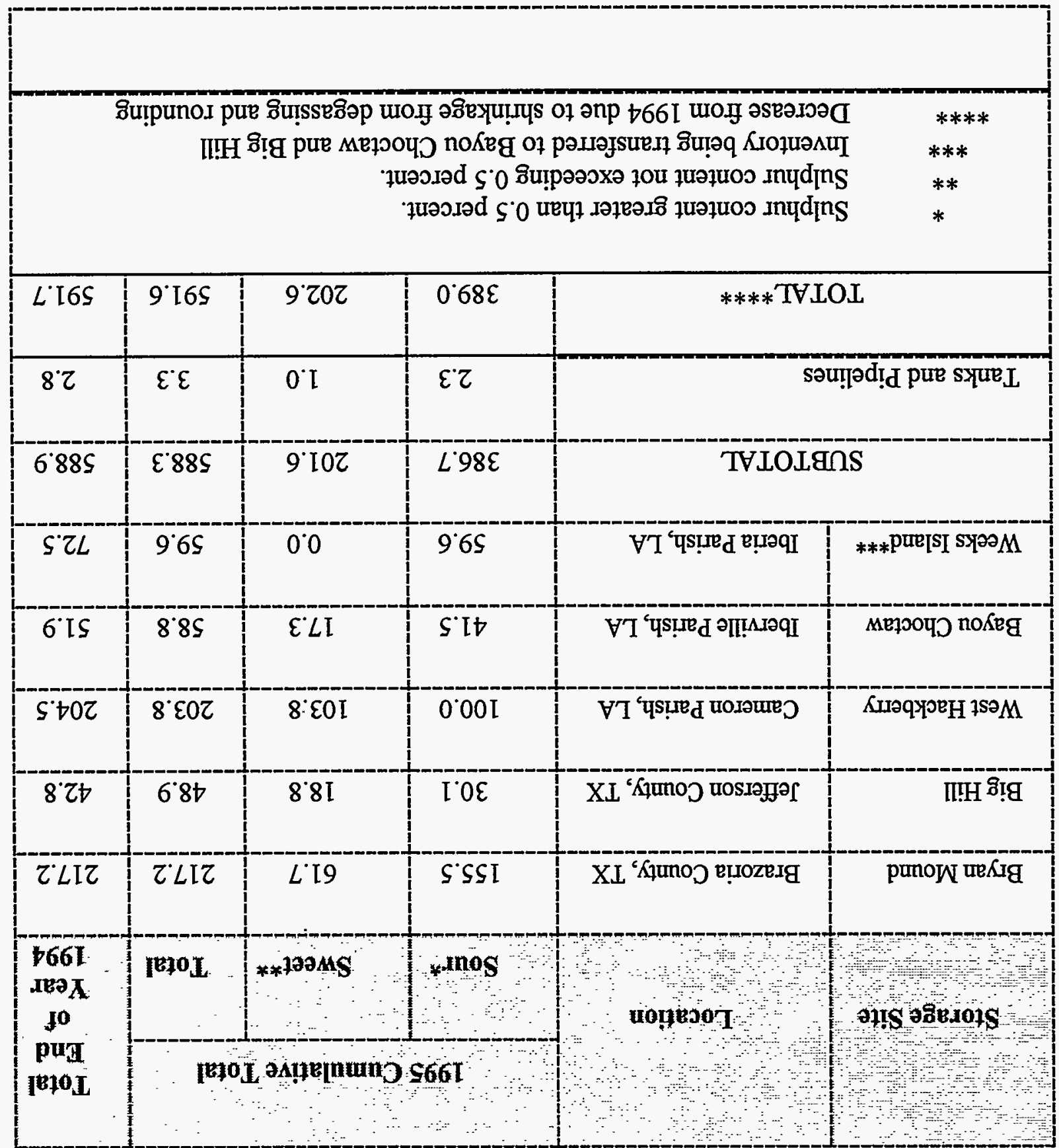

(sjəxגeg uo!II!W)

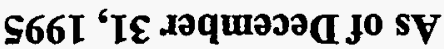

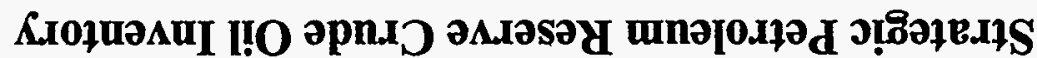

E HTgVL 


\section{OTHER PROJECT ACTIVITIES}

\section{OL STABILIZATION PROGRAM}

During 1995, the Department continued to correct the two related but distinct problems that have temporarily reduced the availability of some Strategic Petroleum Reserve crude oil inventory for drawdown in the near term. The first of these problems is a higher-than-normal gas content in some of the crude oil, apparently from years of intrusion of natural gas from the domal salt, and the second is an elevated temperature of some of the crude oil due to natural geothermal heating. These phenomena have produced an increase in the vapor pressure of the crude oil that could result in emissions that exceed environmental and safe operating limits during a drawdown.

In March 1995, the Department completed its installation of heat exchangers at West Hackberry and Bryan Mound. This will allow for cooling of the crude oil, thereby reducing its vapor pressure at the time of a drawdown. Heat exchangers were previously installed at Bayou Choctaw in late 1994.

During 1995, the Reserve's contractor, Delta Hudson Government Services, Inc., began degassing the approximately 144 million barrels of affected crude oil using two 100,000 barrelsper-day plants. The degassing of 19.1 million barrels at West Hackberry commenced in July and was completed on January 4,1996. The degassing plant at West Hackberry will be moved to Bayou Choctaw for the degassing of approximately 9 million barrels and then to Big Hill where 26 million barrels will be degassed. Operations at Bryan Mound, involving the degassing of 91 million barrels, began in August and are scheduled to be complete by April 1998. As of December 31, 1995, the quantity degassed at Bryan Mound was 11.4 million barrels.

\section{COMMERCIALIZATION OF SPR DISTRIBUTION FACULITIES}

The design of the Strategic Petroleum Reserve's crude oil distribution system has been based on a strategy of making maximum use of commercial crude oil distribution facilities and minimizing the development and operations of facilities to be used exclusively by the Strategic Petroleum Reserve. However, in its development, the Strategic Petroleum Reserve has constructed over 240 miles of crude oil pipelines and one marine terminal to connect its facilities to the commercial infrastructure. With the fill of the Reserve being 80 percent complete and drawdown of the Reserve only required in the event of a national energy emergency, these facilities are largely underutilized. Therefore, in 1994, the Department initiated a "commercialization program" to lease or out grant use of these distribution facilities, i.e. the St. James marine terminal and crude oil pipelines within the Capline, Texoma and Seaway complexes for commercial crude oil distribution. 
The Department issued its first commercialization solicitation in September 1994, inviting industry to submit offers for leasing the St. James Marine Terminal within the Capline complex. Although significant industry interest was expressed in the St. James Terminal, the Department did not receive any lease bids for the terminal when the solicitation closed on February 15, 1995.

In response to receiving no offers for leasing the St. James Terminal, a Strategic Petroleum Reserve Leasing Business Strategy Group met with several firms who previously expressed interest in leasing the facilities in order to understand why no bids were forthcoming. The Business Strategy Group found that the primary reason for industry's nonresponse was (a) a real concern over the Government's lease "terms and conditions" which significantly increased the commercial operating costs and (b) an uncertainty of adequate business revenues.

In August 1995, the Strategic Petroleum Reserve completely restructured its commercialization program. The solicitation for Strategic Petroleum Reserve distribution facilities has been changed to request tat offerors submit a proposal outlining under what terms and conditions they would like to lease the facilities. Following receipt of industry's proposals, the Government will enter into competitive negotiations with the offerors in order to arrive at a lease that is in the best interest of the Government.

Under this new approach, the Department issued a commercialization solicitation on October 24, 1995, inviting industry to submit proposals for leasing two of the Bryan Mound crude oil pipelines within the Seaway complex. Industry proposals for leasing the Bryan Mound crude oil pipelines were due on December 29, 1995 and award is planned for March 1996. The Department plans to issue a similar commercialization solicitation for the its distribution facilities in the Capline system, i.e., the St. James Terminal, the Bayou Choctaw pipeline and the Weeks Island pipeline, in early 1996. With the planned decommissioning of the Weeks Island storage facility, the Department plans to consider sale as well as lease offers for the Weeks Island pipeline and the St. James Terminal. If the Department is not able to commercialize or sell the St. James Terminal, it will pursue mothballing the facility. 


\section{PROCUREMENT AND CONTRACTOR SUPPORT}

Obligations in fiscal year 1995 for Strategic Petroleum Reserve program activities totaled approximately $\$ 214.5$ million. Of this amount, $\$ 10.6$ million was obligated for Federal program management salaries and benefits and $\$ 203.9$ million was obligated for contractual goods and services to operate and maintain the Strategic Petroleum Reserve.

The Strategic Petroleum Reserve's two prime contractors during 1995 were DynMcDermott Petroleum Operations Company, the management and operating contractor; Walk Haydel and Associates, the architect-engineering services contractor; Mitre Corporation, the systems engineering services contractor; and Tucker and Associates, Inc., the management and technical support services contractor.

Other prime contractors who provided services to the Strategic Petroleum Reserve during 1995 included: Arco Pipe Line Company, Phillips Petroleum Company, Sun Pipe Line Company, Sun Marine Terminals, Texaco Pipeline, Inc., and Union Oil Company of California for crude oil transportation and terminalling services; River Valley Services, Inc., L.S. Womack, Inc., and Maitland Brothers for construction; Vindicator Corporation for security systems; Fisher-Rosemont Systems for control systems; and Gulf States Utilities Company and Houston Lighting and Power Company electrical power.

\section{REAL ESTATE ACTIONS}

The Department of Energy obtained, through the U.S. Army Corps of Engineers on February 6, 1995, a 20-year permit to use a portion of the Port Allen radio station at Port Allen Lock, West Baton Rouge Parish, Louisiana.

On February 15, 1995, no proposals were received from any of the 37 companies solicited in leasing the St. James Terminal.

On April 21, 1995, the Department of Energy obtained a right of entry from Morton International, Inc., to construct a freeze wall and clear vegetation on their property for the Weeks Island oil movement project.

The Department of Energy issued a license agreement to Amoco to conduct seismic operations across the West Hackberry facility on May 17, 1995.

In October 1995, the U.S. Army Corps of Engineers acquired 1.39 acres of property for the West Hackberry brine relining project and 4.72 acres on the Weeks Island facility. 


\section{SECURITY}

DynMcDermott Petroleum Operations Company, under its management and operating contract, is assigned responsibility to implement and administer the Department of Energy's Strategic Petroleum Reserve Security Program. DynMcDermott secures protection services through a subcontract with Wackenhut Services, International. The Strategic Petroleum Reserve currently has a protection force of 199 armed officers, a reduction of about 10 percent from 1994 as a result of the Reserve's continuing streamlining effort.

The Strategic Petroleum Reserve enhanced vigilance of all security protection officers and implemented increased security protective measures as a result of the April 19, 1995, Oklahoma City Federal building bombing. These security enhancements continue as part of the Strategic Petroleum Reserve Security Program.

During 1995, following a recommendation from the Department of Energy's Office of Security Evaluations, the Strategic Petroleum Reserve conducted a Consequence Analysis to determine and validate Strategic Petroleum Reserve Security Program capabilities. The Consequence Analysis was conducted at each Strategic Petroleum Reserve site under the full range of potential threats, utilizing Field Training Exercises, which included multiple integrated laser engagement system (MILES) evaluation of the security systems, and protective force capabilities. All exercises had satisfactory results. As a continuing part of the Strategic Petroleum Reserve security training program, Acceptance and Validation Field Test Exercises will continue to be conducted on an annual basis. 


\section{ENVIRONMENT, SAFETY AND HEALTH}

\section{ENVIRONMENTAL COMPLIANCE}

During the year, the Strategic Petroleum Reserve completed environmental reviews pursuant to the National Environmental Policy Act (NEPA) for leasing St. James Terminal and for decommissioning Weeks Island. The Environmental Assessment on the Leasing of the Strategic Petroleum Reserve St. James Terminal (DOE/EA-1003) was approved and a Finding of No Significant Impact was issued in January 1995. It was determined that increased crude oil throughput at St. James under a commercial lease would result in minor impacts to air quality; oil spill risk would not change substantially. For other potential commercialization actions, such as leasing pipelines, NEPA review would be conducted in conjunction with the competitive procurement process.

The Reserve approved the Environmental Assessment for Decommissioning the Strategic Petroleum Reserve Weeks Island Facility, Tberia Parish, Louisiana (DOE/EA-1051) and issued a Finding of No Significant Impact in December 1995. Decommissioning activities are not expected to result in any short-term, long-term, or cumulative impacts. Based on a risk analysis comprising probability and consequence, it was concluded that the principal concerns associated with decommissioning actions-- a release of oil to groundwater or surface waters and worsening subsidence-- were either unlikely or highly unlikely. Significant risks would be associated, however, with doing nothing (the no action alternative).

In July, the Reserve received a National Pollutant Discharge Elimination System permit from the Environmental Protection Agency for Bryan Mound's replacement brine disposal pipeline and diffuser. The unit is now in operation. Other permits obtained during the year were air operating permits for degasification units at Bryan Mound, West Hackberry, and Bayou Choctaw. A variance was obtained from Louisiana for the St. James air permit to allow for the possible sale of 7 million barrels of crude oil in the absence of a declared emergency.

Emergency Planning and Community Right-to-Know Act Section 312 reports were prepared and provided to State and local authorities as required. In recognition of the sites' continuing status as small quantity generators of hazardous waste, however, the Department exempted the Reserve from the requirement for the Annual Report on Waste Generation and Waste Minimization, thereby saving an estimated 280 man-hours. 


\section{OTHER ENVIRONMENTAL, SAFETY AND HEALTH ACTIONS}

\section{EMERGENCY MANAGEMENT EXERCISE}

On November 15 and 16, the Strategic Petroleum Reserve conducted its annual emergency management exercise, EMEX 11. This exercise was performed to demonstrate the Reserve's ability to respond to a major oil spill, as well as test the management of a spill clean-up operation after the initial response. EMEX 11 involved emergency response teams from the Reserve's Bryan Mound, Big Hill and West Hackberry storage sites responding to a simulated commercial pipeline spill into Highland Bayou at LaMarque, Texas, and included the participation of the U.S. Coast Guard, Environmental Protection Agency, and various State of Texas regulatory agencies. EMEX 11 was the first Strategic Petroleum Reserve exercise involving three sites and utilized the Incident Command System developed by the National Interagency Fire Center. The exercise also satisfied the requirement of the National Preparedness for Response Exercise Program guidelines for compliance with the Oil Pollution Act of 1990 . 


\section{BUDGET AND FINANCE}

\section{MAJOR BUDGET AND FINANCING ACTIONS DURING 1995}

As of December 31, 1995, the Interior and Related Agencies Appropriations, FY 1996, had not been enacted. Funding for the Strategic Petroleum Reserve was provided through the use of carryover funds from fiscal year 1995 and through a series of short-term continuing resolutions.

H.R. 1977, the Department of Interior and Related Agencies Appropriations Bill, FY 1996 , as approved by the Senate and the House, would provide $\$ 287$ million for Strategic Petroleum Reserve facilities operations and management through the transfer of $\$ 187.0$ million from prior year balances in the SPR Petroleum Account and use of $\$ 100.0$ million from a proposed sale of crude oil associated with the Weeks Island decommissioning. The bill also included an outlay limitation of $\$ 5$ million for the Strategic Petroleum Reserve Account. The bill was vetoed by the President and the veto was sustained by the Congress.

\section{STRATEGIC PETROLEUM RESERVE ACCOUNT}

The Strategic Petroleum Reserve Account funds the development, operation, and maintenance of Reserve facilities; the salaries and expenses necessary to plan and manage the program, including the operation of the Project Management Office in New Orleans, Louisiana; and the activities pertinent to major issues concerning the development and use of the Strategic Petroleum Reserve. Appropriations of \$244 million were enacted for fiscal year 1995; of which $\$ 49$ million remained available for obligation at the end of fiscal year 1995. These balances are associated with workload carried into fiscal year 1996.

\section{SPR PETROLEUM ACCOUNT}

The SPR Petroleum Account funds the acquisition of oil for the Strategic Petroleum Reserve; the associated costs for transportation and terminalling; U.S. customs duties, Superfund and Oil Spill Liabilities Trust Fund taxes; and other miscellaneous costs, such as Defense Fuel Supply Center administration costs associated with acquiring and transporting oil. In the event of a drawdown and sale of Strategic Petroleum Reserve oil, the SPR Petroleum Account also funds the costs of withdrawing oil from the storage caverns and transporting it to the point where the purchasers take title. An amount equal to Federal receipts from a drawdown and sale is deposited in the SPR Petroleum Account and creates additional budget authority for refilling the Reserve. At the end of fiscal year 1995, $\$ 220$ million remained available for obligation in the SPR Petroleum Account, of which $\$ 187$ million is proposed for transfer to the Strategic Petroleum Reserve Account. No additional funds were appropriated during 1995. 


\section{APPROPRIATIONS THROUGH FY 1995}

A total of $\$ 21$ billion has been appropriated for the Strategic Petroleum Reserve through fiscal year 1995. Included in this total are the distribution of annual and total appropriations as shown in Table 4. Figures 4 and 5 illustrate annual and cumulative appropriations for storage facilities operations and management and petroleum acquisition and transportation.

\section{OIL COSTS THROUGH FISCAL YEAR 1995}

The cumulative cost for the oil in the Strategic Petroleum Reserve at the end of fiscal year 1995 was $\$ 16$ billion for an average cost of approximately $\$ 27.14$ per barrel. Cumulative oil cost for the Department of Defense inventory at the end of fiscal year 1995 was $\$ 125$ million for an average cost of $\$ 19.32$ per barrel. 


\section{FIGURE 4}

\section{STRATEGIC PETROLEUM RESERVE ANNUAL FUNDING}

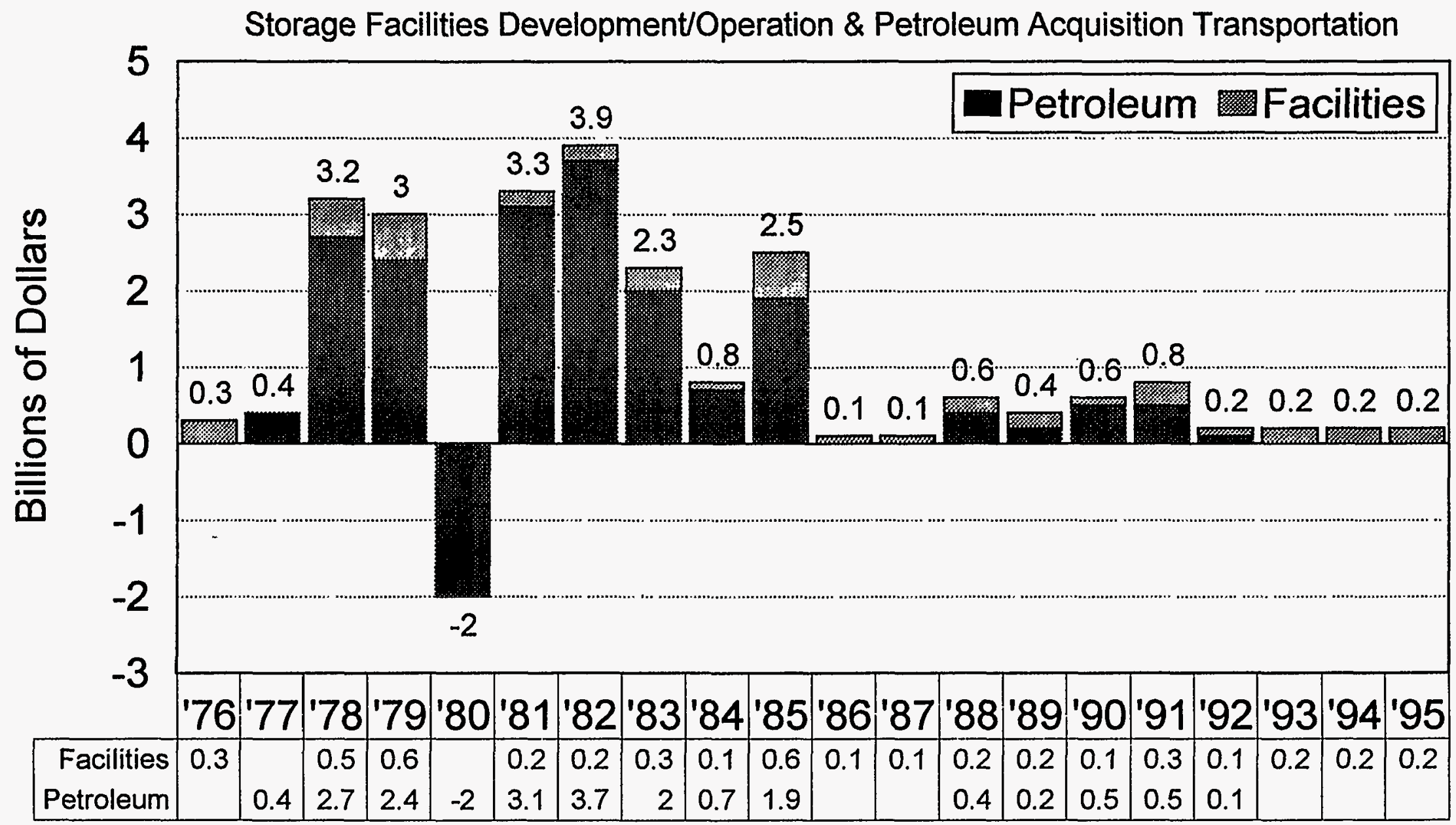

Fiscal Year 
FIGURE 5

STRATEGIC PETROLEUM RESERVE CUMULATIVE FUNDING

Storage Facilities Development/Operation \& Petroleum Acquisition Transportation

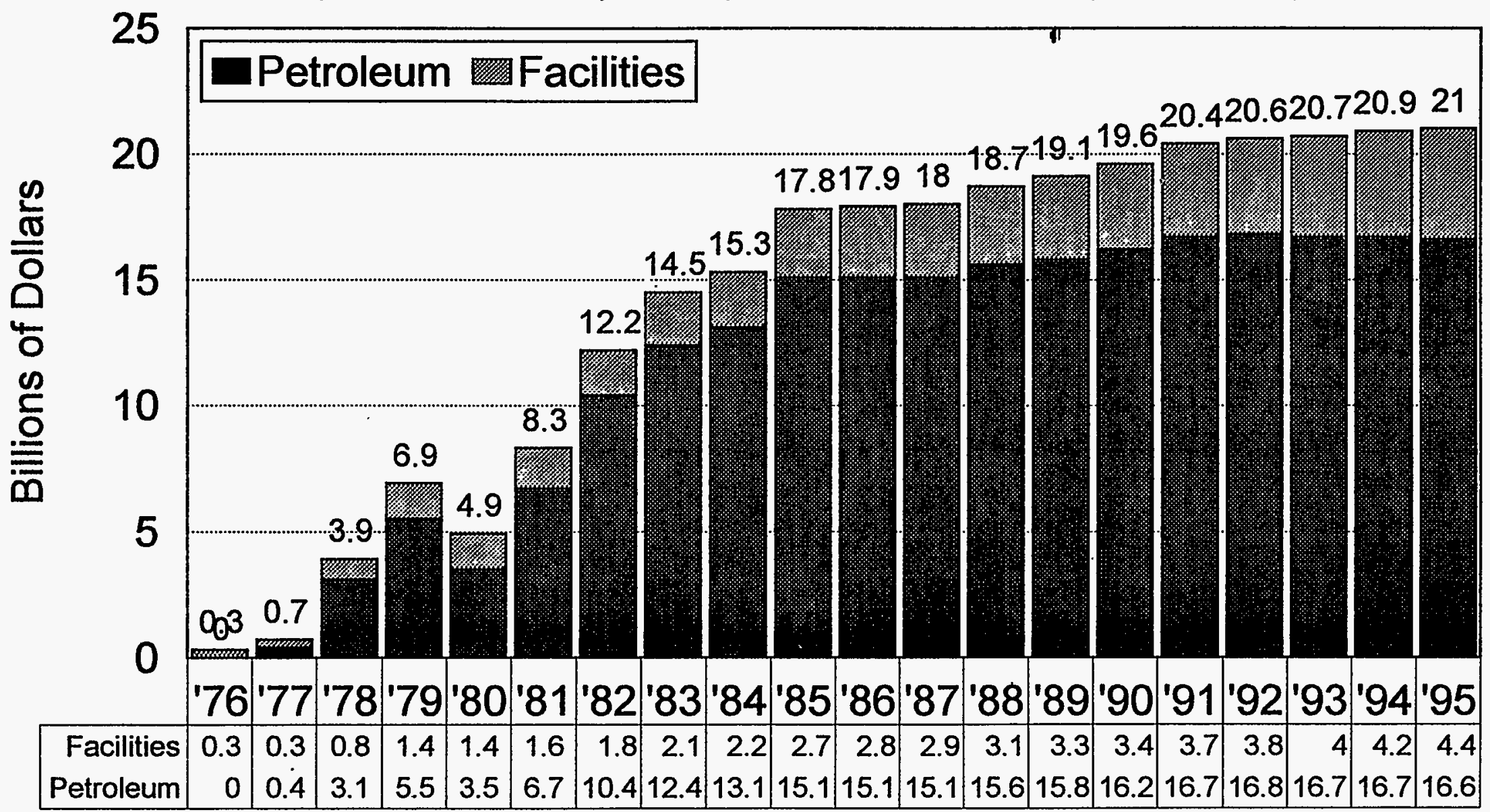

Fiscal Year 
TABLE 4

STRATEGIC PETROLEUM RESERVE APPROPRIATIONS

\begin{tabular}{|c|c|c|c|c|c|}
\hline FY & Oil Account & Facilities & Management & Total & Defense SPF \\
\hline 1976 & 0 & 300,000 & 13,975 & 313,975 & \\
\hline 1977 & 440,000 & 0 & 7,824 & 447,824 & \\
\hline 1978 & $2,703,469$ & 463,933 & 14,704 & $3,182,106$ & \\
\hline 1979 New BA & $2,885,670$ & 103,290 & 18,111 & $3,007,071$ & \\
\hline Reprogrammings & $(529214)$ & $\underline{529214}$ & $\underline{0}$ & $\underline{Q}$ & \\
\hline Total 1979 Appropriations & $2,356,456$ & 632,504 & $18,11 \overline{1}$ & $3,007,071$ & \\
\hline $\begin{array}{l}1980 \text { Rescission } \\
1980 \text { Reprogrammings }\end{array}$ & $(2,000,000)$ & & & $(2,000,000)$ & \\
\hline No 1 & $(20,391)$ & 0 & 20,391 & 0 & \\
\hline No 2 & $(1,881)$ & $\underline{0}$ & 1,881 & $\underline{Q}$ & \\
\hline Total 1980 Appropriations & $(2,022,272)$ & $\mathbf{0}$ & 22,272 & $(2,000,000)$ & \\
\hline 1981 & $2,688,282$ & 82,834 & 19,391 & $2,790,507$ & \\
\hline Entitlements & 542,146 & $\mathbf{0}$ & 0 & 542,146 & \\
\hline Reprogrammings & & & & & \\
\hline No 1 & $(18,000)$ & 18,000 & 0 & 0 & \\
\hline No 2 & $(7,334)$ & $\underline{7,334}$ & & $\underline{\mathbf{0}}$ & \\
\hline Total 1981 Appropriations & $3,205,094$ & 108,168 & 19,391 & $3,332,653$ & \\
\hline 1982 & $3,684,000$ & 171,356 & 20,076 & $3,875,432$ & \\
\hline Reprogrammings & $(4,300)$ & 4,300 & & $\underline{\mathbf{0}}$ & \\
\hline Total 1982 Appropriations & $3,679,700$ & 175,656 & 20,076 & $3,875,432$ & \\
\hline 1983 & $2,074,060$ & 222,528 & 19,590 & $2,316,178$ & \\
\hline 1984 & 650,000 & 142,357 & 16,413 & 808,770 & \\
\hline 1985 & $2,049,550$ & 441,300 & 17,890 & $2,508,740$ & \\
\hline 1986 & 0 & 94,015 & 13,518 & 107,533 & \\
\hline Reprogrammings & $(12,964)$ & 12,964 & $\underline{\mathbf{0}}$ & $\underline{0}$ & \\
\hline Total 1986 & $(12,964)$ & 106,979 & $13,51 \overline{8}$ & 107,533 & \\
\hline 1987 & 0 & 134,021 & 13,412 & 147,433 & \\
\hline 1988 & 438,744 & 151,886 & 12,276 & 602,906 & \\
\hline 1989 & 242,000 & 160,021 & 13,400 & 415,421 & \\
\hline & 371,916 & 179,530 & 12,953 & 564,399 & \\
\hline 1991 & 566,318 & 187,728 & 12,846 & 766,892 & \\
\hline 1992 & 88,413 & 171,678 & 13,384 & 273,475 & \\
\hline 1993 & $(125,625)$ & 161,940 & 14,227 & 50,542 & \\
\hline DOD Transfer (non add) & 124,925 & 700 & 0 & 125,625 & 125,625 \\
\hline 1994 & 0 & 191,035 & 15,775 & 206,810 & \\
\hline 1995 & $(107,764)$ & 226.938 & 16,780 & 135,954 & \\
\hline Total Thru FY 1995 & $16,597,095$ & $4,158,202$ & 308,817 & $21,064,114$ & 125,625 \\
\hline 1996 (House/Senate; transfer) & $(187,000)$ & 170,173 & 16,827 & 0 & \\
\hline 1996 (House/Senate; sell $7 \mathrm{mmb}$ & $(100,000)$ & 100,000 & 0 & 0 & \\
\hline 1996 (Total House/Senate) & $(287,000)$ & 270,173 & 16,827 & 0 & \\
\hline Total Incl FY 1996 Req. & $16,310,095$ & $4,428,375$ & 325,644 & $21,064,114$ & 125,625 \\
\hline
\end{tabular}

Note: FY 1991 SPR Petroleum Account of $\$ 566,318$ includes proceeds of $\$ 122,681$ from the Test Sale authorized by the President on September 26, 1990, pursuant to the EPCA authorities enacted September 15, 1990 , in P.L. 101-383. These proceeds are recorded as additional budget authority rather than reductions to obligations, costs, and outlays. It also includes \$315,424,985 in Desert Storm Drawdown proceeds and $\$ 19,755,064$ from FY 1991 NPR excess receipts. Thus the cumulative budget authority is "gross" and not related directly to the inventory of oil on hand.

Defense SPR (FY 93) includes $\$ 700,000$ for M\&O activities

Facilities FY 94 includes $\$ 34,100$ for the hot/gassy oil remediation program.

FY 1996 Appropriation not passed as of February 15, 1996. 


\section{DRAWDOWN AND DISTRIBUTION}

\section{DISTRIBUTION PLAN}

In the event of a drawdown to respond to a severe energy supply interruption, or to meet obligations of the United States under the Agreement on an International Energy Program, the current plan for distributing crude oil is provided in the "Strategic Petroleum Reserve Drawdown (Distribution) Plan," Amendment Number 4 to the Strategic Petroleum Reserve Plan submitted on December 1, 1982. The Strategic Petroleum Reserve Distribution Plan provides that, pursuant to the President's decision to use the Strategic Petroleum Reserve, the principal method of distributing Strategic Petroleum Reserve oil will be by price competitive sale and the oil is sold and delivered to those offering the highest prices. The sale is open to the largest possible universe of eligible buyers to ensure efficient distribution of Strategic Petroleum Reserve oil. The plan also provides that, in any calendar month, the Secretary of Energy may direct the distribution of up to 10 percent of the volume of oil sold in that calendar month. The price for such oil will be the average price of Strategic Petroleum Reserve oil sold at the contemporaneous competitive sale or at the most recent competitive sale if no contemporaneous competitive sale is held.

\section{COMPETITIVE SALES PROCEDURES}

Appendix A to the Department of Energy's final rule (10 CFR Part 625) governing price competitive sales of petroleum from the Strategic Petroleum Reserve provides for Standard Sales Provisions containing or describing contract clauses, terms and conditions of sale, and performance and financial responsibility measures, which may be applicable to a particular sale of Strategic Petroleum Reserve oil. The most recent edition of the Standard Sales Provisions was published in the Federal Register on December 11, 1992.

Under the Standard Sales Provisions, the Strategic Petroleum Reserve sales process begins with the issuance of a Notice of Sale specifying the amount, characteristics, and location of the petroleum being sold as well as the delivery dates and the procedures for submitting offers and other information pertinent to a particular sale. In addition, the Notice of Sale specifies which sales provisions and performance and financial responsibility measures apply.

During the course of a Strategic Petroleum Reserve drawdown, several Notices of Sale may be issued, each covering a sales period of one to two months. Initially, Notices of Sale could allow an extremely short lead time for offers and deliveries. Under the Standard Sales Provisions, it is contemplated that offerors might be given as little as seven days from the date of issuance until offers are due, and 30 days or less from the time of such issuance until the purchasers must accept delivery of the oil, with a less compressed schedule becoming more feasible after the initial stages of drawdown. Because of the possible short lead time, the 
Standard Sales Provisions provide for establishing a list of prospective offerors who will receive all Notices of Sale.

The next step in the sales process is the submission of offers by prospective purchasers at a time specified in the Notice of Sale. The Standard Sales Provisions require that the offerors unconditionally accept all terms and conditions in the Notice of Sale, including an offer guarantee of $\$ 10$ million, or 5 percent of the maximum potential contract amount, whichever is less, and an offer of at least the minimum price, if any, specified in the Notice of Sale.

When offers are received, they are evaluated to select the "apparently successful" offerors. The evaluation process is structured so that the offerors bidding the highest prices can select a method of transportation, up to the limits of the Strategic Petroleum Reserve distribution systems, with specific delivery arrangements negotiated later in the process.

Under the Standard Sales Provisions, all "apparently successful offerors" are required, within five business days after being notified, to provide a Letter of Credit equal to 100 percent of the contract amount, or a cash deposit in an amount equal to 110 percent of the contract value, as a guarantee of performance and payment of amounts due under the contract.

Upon timely receipt of the financial guarantees, and upon a final determination by the Contracting Officer that the offers were responsive and the offerors responsible, the Department of Energy issues the Notices of Award and commences deliveries of oil from the Reserve to the purchasers, consistent with their arrangements for commercial pipeline or marine vessel transportation. Such deliveries can begin as soon as the 16th day after the commencement of the sales process, to the extent that the purchasers can submit their financial guarantees and arrange transportation expeditiously.

\section{DRAWDOWN AND DISTRIBUTION CAPABILITIES}

The crude oil in the Strategic Petroleum Reserve is commingled in storage to allow for eight distinct crude oil streams to be sold in the event of a drawdown. Table 5 describes these streams and their inventories, as of December 31, 1995, their typical characteristics and available delivery modes and locations.

The Reserve's drawdown and distribution capabilities are shown in Table 6. These capabilities are based on the current crude oil stream inventories, excluding oil inventory that is unavailable for drawdown due to excess gas content, and the existing drawdown systems and commercial distribution capabilities. These capabilities provide for the drawdown and distribution of Strategic Petroleum Reserve crude oil at an initial sustainable rate of 3.4 million barrels per day for a period of 90 days. After this initial period, the drawdown/distribution rate would decrease gradually as site inventories are depleted and the declining number of caverns 
containing crude oil becomes a constraint. Figure 6 illustrates the Strategic Petroleum Reserve's physical drawdown/distribution capability which provides for a distribution of 305 million barrels in 90 days and 453 million in 180 days. The Reserve is also capable of increasing the total amount of inventory drawn down if it is drawn at a lesser initial rate since slower rates allow for greater cooling in distribution pipelines, thereby lowering the vapor pressure of the oil.

Over the next two years as the excess gas problem is corrected by means of the degasification project, the Reserve's capability to drawdown its total inventory will gradually increase to a rate of 3.9 million barrels per day by April 1998. 
TABLE 5

STRATEGIC PETROLEUM RESERVE CRUDE OIL STREAMS*

\begin{tabular}{|c|c|c|c|c|}
\hline $\begin{array}{l}\text { CRUDE OIL } \\
\text { STREAM }\end{array}$ & $\begin{array}{l}\text { INVENTORY } \\
\text { (MMB) }\end{array}$ & $\begin{array}{l}\text { TYPICAL API } \\
\text { GRAVITY }\end{array}$ & $\begin{array}{c}\text { TYPICAL } \\
\text { SULFUR } \\
\text { CONTENT }\end{array}$ & $\begin{array}{l}\text { DELIVERY MODE AND } \\
\text { LOCATION . }\end{array}$ \\
\hline 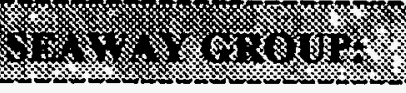 & 12 & 2 & 4 & 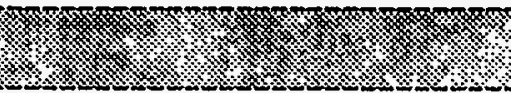 \\
\hline Bryan Mound Sweet & 61.7 & $36.0^{\circ}$ & $0.34 \%$ & \multirow{2}{*}{$\begin{array}{l}\text { Pipeline or tankship at } \\
\text { Phillips Terminal, Freeport, } \\
\text { TX or Arco Terminal, Texas } \\
\text { City TX }\end{array}$} \\
\hline Bryan Mound Sour & 144.4 & $33.1^{\circ}$ & $1.51 \%$ & \\
\hline Bryan Mound Maya & 11.1 & $22.8^{\circ}$ & $3.28 \%$ & Tankship at Phillips Terminal \\
\hline \multicolumn{5}{|l|}{$34,6,6,061$} \\
\hline $\begin{array}{l}\text { West Hackberry } \\
\text { Sweet** }\end{array}$ & 122.3 & $36.9^{\circ}$ & $0.31 \%$ & \multirow{2}{*}{$\begin{array}{l}\text { Pipeline , tankship or barge } \\
\text { at Sun Terminal, Nederland, } \\
\text { TX; Tankship at Unocal } \\
\text { Terminal, Nederland, TX; } \\
\text { Pipeline at Texaco-22/DOE } \\
\text { connection, Lake Charles, } \\
\text { LA; Pipeline at Texaco- } \\
\text { 20/DOE connection, } \\
\text { Houston, TX }\end{array}$} \\
\hline $\begin{array}{l}\text { West Hackberry } \\
\text { Sour** }\end{array}$ & 125.0 & $33.7^{\circ}$ & $1.44 \%$ & \\
\hline \multicolumn{5}{|l|}{ 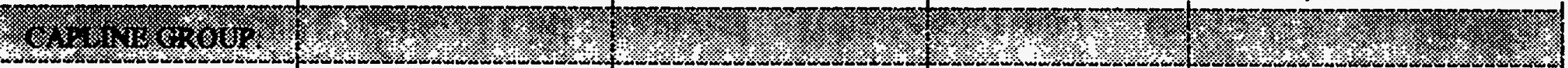 } \\
\hline Weeks Island Sour & 72.5 & $28.9^{\circ}$ & $1.41 \%$ & \multirow{3}{*}{$\begin{array}{l}\text { Pipeline at Capline or } \\
\text { LOCAP Terminals, St. } \\
\text { James, LA; Tankship at } \\
\text { DOE's Terminal, St. James, } \\
\text { LA }\end{array}$} \\
\hline Bayou Choctaw Sweet & 17.4 & $36.1^{\circ}$ & $0.39 \%$ & \\
\hline Bayou Choctaw Sour & 34.5 & $33.2^{\circ}$ & $1.47 \%$ & \\
\hline \multicolumn{5}{|c|}{ Data as of December 311994} \\
\hline & & ude oil & & \\
\hline
\end{tabular}




\section{TABLE 6 \\ SPR DRAWDOWN AND DISTRIBUTION CAPABILITIES \\ (Thousands Of BarRels Per DAY)}

\begin{tabular}{|c|c|c|}
\hline & (12: & : \\
\hline Seaway Group & 525 & 1250 \\
\hline Texoma Group & 1587 & 1940 \\
\hline Capline Group & 985 & 1070 \\
\hline TOTAL & 3100 & 4260 \\
\hline
\end{tabular}




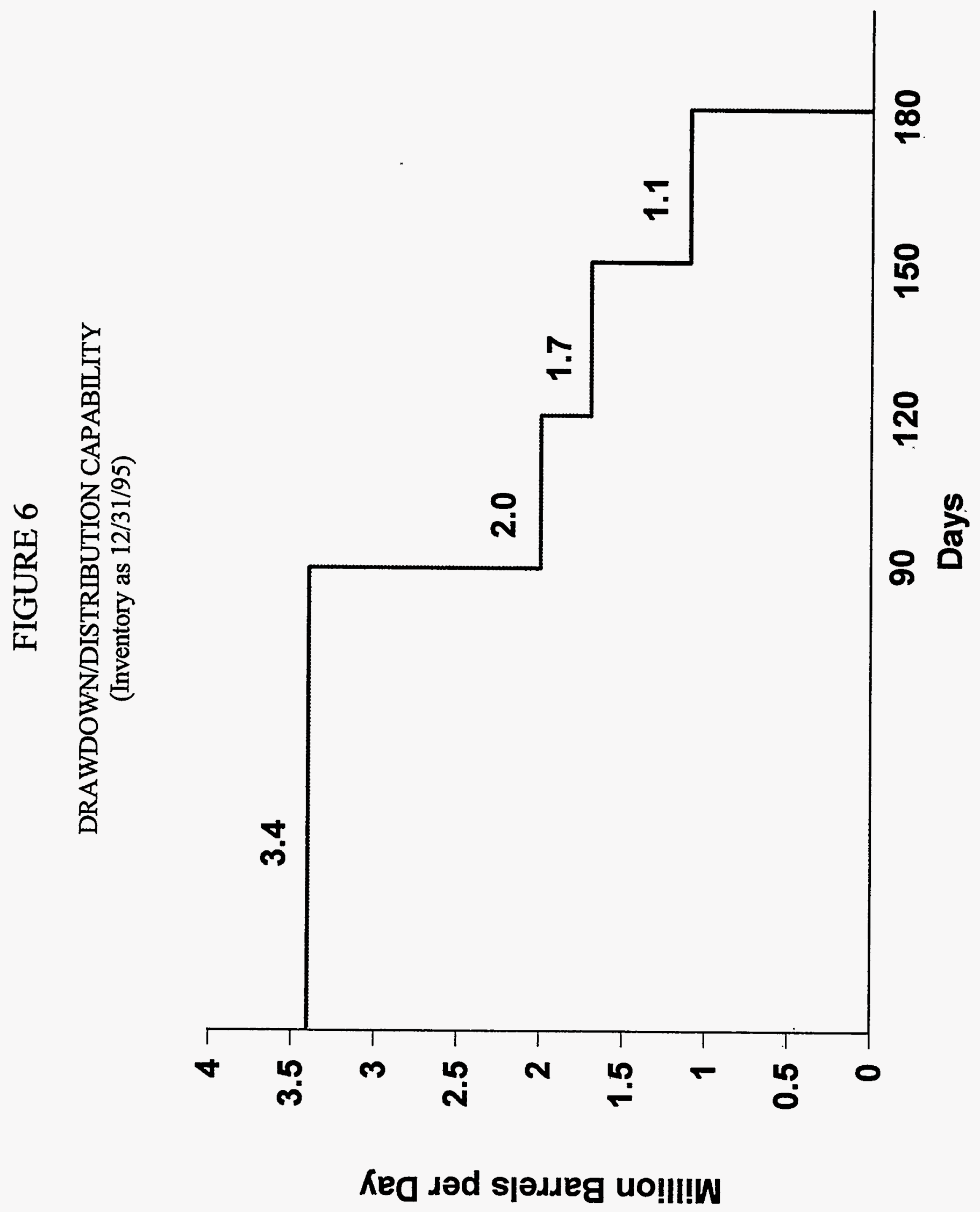




\section{DRAWDOWN READINESS ACTIVITIES}

During 1995, the Strategic Petroleum Reserve continued to perform various activities under its drawdown readiness assurance program which is designed to maintain the Reserve in a state of readiness to conduct a drawdown and distribution of the Reserve's inventory in the event of a requirement. These activities included:

- $\quad$ Conducting Quarterly Drawdown Readiness Reviews, encompassing each function and system associated with a drawdown;

- Enhancing the drawdown readiness program through initiating plans for periodically conducting tabletop exercises at each site, mini-administrative exercises of the sales process and unannounced physical drawdown tests, as well as developing a graphical readiness integrated drawdown system that will use a computer-based system to assist in evaluating the Reserve's readiness;

- Conducting physical testing of various site equipment and systems and performing administrative exercises of the drawdown process;

- Conducting assessments of the distribution terminals' readiness to support a drawdown;

- Developing improvements to various computer models used in assessing drawdown capabilities and supporting drawdown operations;

- Initiating a performance-based training program for all drawdown-critical positions in both the Reserve and contractor organizations; and

- $\quad$ Analyzing the Reserve's drawdown capabilities based on the constraints imposed by various problems or physical conditions/limitations, such as excessive gas and temperature conditions, equipment failures and distribution terminal changes. 


\section{CUSTOMER SERVICE TO THE NATION AND TO U.S. REFINERS}

The Strategic Petroleum Reserve serves both the Nation and U.S. refiners by providing energy security against potential disruptions in petroleum supplies, and by providing refiners maximum accessibility to the Nation's stockpile in the event of a disruption. As of December 31, 1995, the inventory of crude oil in the Reserve amounted to 592 million barrels, providing a net import protection level of 72 days, based on the 1995 net import rate for crude and petroleum products.

The Strategic Petroleum Reserve is designed to distribute crude oil to U.S. refiners through local and interstate commercial pipelines systems and marine terminals. The Reserve is currently accessible to 51 active refiners by commercial pipelines. In 1995, these 51 refiners comprised approximately 50 percent of U.S. refining capacity, and processed approximately 48 percent of all non-Canadian crude oil imports.

During 1995, two major commercial pipeline projects were initiated which enhance the SPR's pipeline distribution capabilities to Midwest and midcontinent refineries. In April 1995, Mobil completed the reversal of its 20-inch pipeline from Nederland, Texas to Corsicana, Texas. This pipeline now provides the capability to transport SPR oil from Sun Terminal in Nederland, Texas to Patoka, Illinois in the Midwest at a rate of 200,000 barrels per day. Also during early 1995, ARCO and Phillips Petroleum Co. formed a pipeline partnership to reconvert the Seaway 30-inch pipeline from natural gas to crude oil service. This pipeline will provide the capability to transport SPR oil from Freeport, Texas to Cushing, Oklahoma at an initial rate of 270,000 barrels per day in early 1996. These two projects aimed at satisfying industry's growing demand for imported crude in the Midwest and midcontinent, add flexibility to the SPR's distribution capabilities.

The Reserve is also connected to five marine terminals for waterborne distribution: Phillips in Freeport, Texas, ARCO in Texas City, Texas, Sun and Unocal in Nederland, Texas, and the Department of Energy's St. James Terminal in St. James, Louisiana. These terminals have a total of 13 tanker berths and three barge berths, with a combined shipping capacity of 2.4 million barrels of crude oil per day. Figure 7 shows the Reserve's pipeline and marine distribution capabilities. 


\section{FIGURE 7}

\section{STRATEGIC PETROLEUM RESERVE PIPELINE AND MARINE DISTRIBUTION CAPABILITIES}

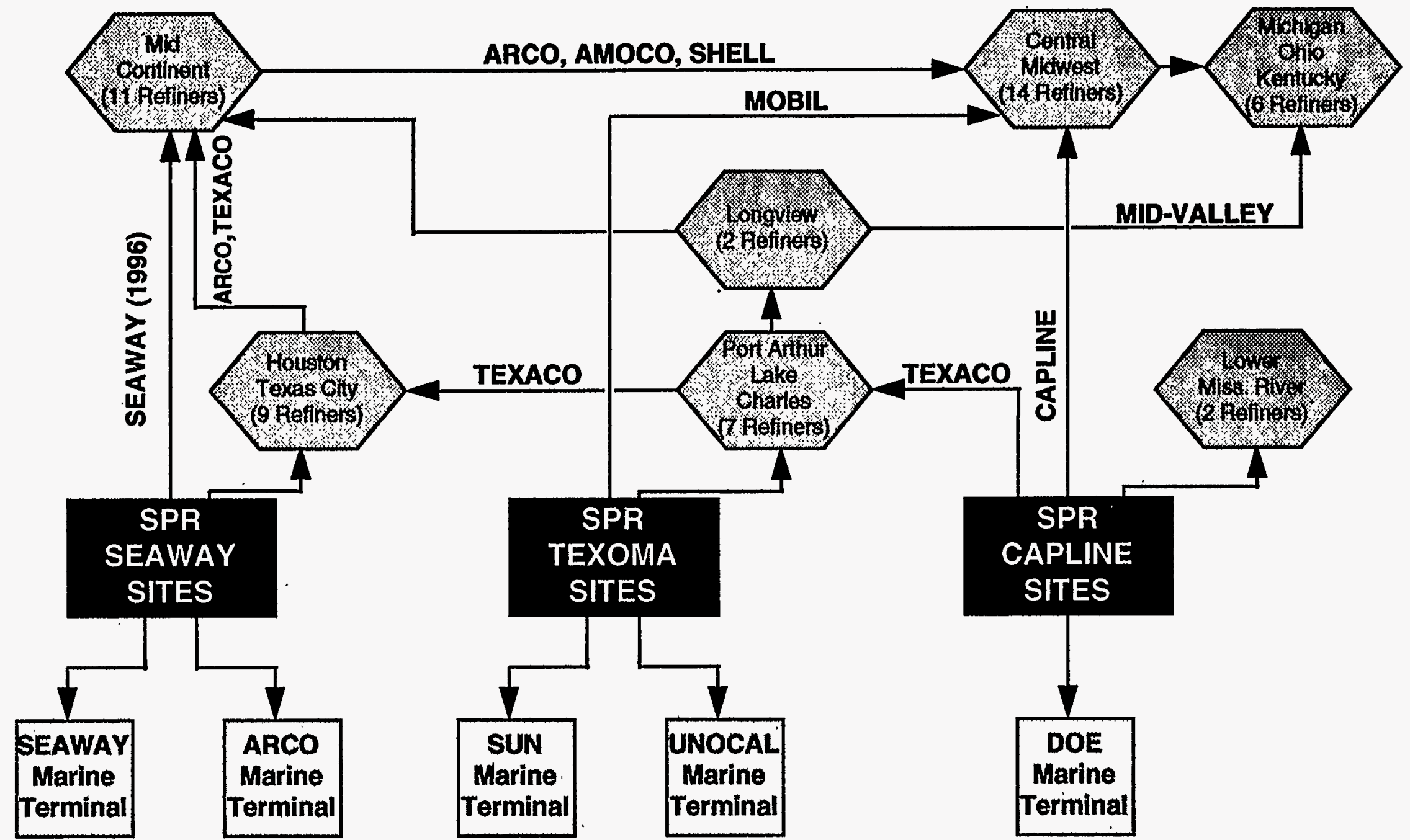




\section{CONTINUOUS QUALITY IMPROVEMENT}

The Strategic Petroleum Reserve's continuous quality improvement program matured significantly in 1995. The Program Office, Project Management Office, DynMcDermott, and sites all have active quality councils and are conducting process improvement projects. DynMcDermott, the SPR's management and operations contractor, won a 1995 Department of Energy Quality Commendation Award, which is based on the Malcolm Baldridge National Quality Award criteria.

The SPR has seen increasing savings of time and money, elimination of unnecessary or low value work, and simplification of processes as employees have become more sophisticated in using continuous quality improvement methods. These improvements have been celebrated at the SPR's annual Quality Expo in New Orleans since 1994. The Quality Expo publicly recognizes SPR employees, promotes replication of successful quality improvements throughout the SPR, and promotes further use of continuous quality improvement methods. Annual competitions among the best SPR quality improvement projects are held at each expo.

One winning team from the 1994 Quality Expo, along with SPR management and quality improvement staff, briefed the Secretary of Energy at her senior staff meeting on January 23, 1995. That team, from West Hackberry, created a statistical testing and tracking program that eliminated noncompliant water samples and enabled the SPR to cancel a planned and budgeted $\$ 100,000$ plant modification that was designed to accomplish the same purpose.

Examples of 1995 project results follow. Some process improvement teams are comprised of personnel located at single sites, while teams that deal with broader improvement topics may have members from several sites or organizations. Several teams include Federal employees, contractors, and even subcontractors as members.

- $\quad$ One winning Bryan Mound team at the 1995 Quality Expo used quality improvement methods to study and eliminate an inspection requirement that did not add value, saving 1,090 man-hours annually.

- An engineering design review team reduced the time to complete reviews by 22 percent, reduced resources requirements by 18 percent, and improved the completeness of packages by 18 percent.

- $\$ 361,000$ in labor costs were saved annually by streamlining the requirements for escorting vendors for security purposes. 
- West Hackberry site teams have significantly reduced negative findings in internal assessments of fire extinguisher compliance (from 51 findings in 1994 to no findings in 1995) and audits of accounting for hazardous materials and chemical inventories (reduction of 80 percent in findings).

- Annual savings of $\$ 383,000$ in labor and $\$ 60,000$ in contractor costs were achieved by improving performance standards and training materials in environment, safety and health and in heavy equipment refresher training.

In 1996, the SPR will continue its improvement efforts and will further develop its employees' capabilities in continuous quality improvement. Joint process improvement efforts involving headquarters (Program Office) and field (Project Management Office) personnel are planned, as are efforts that will focus more on the SPR's customers. DynMcDermott is working on a major reengineering project, that will completely redesign inventory management, warehousing, property control, purchasing, and financial forms processing, including developing new supporting information systems. 


\section{LOOKING AHEAD TO 1996}

The Department will be involved in the following significant activities in the year 1996.

\section{CRUDE OIL SALE}

In late 1995, pursuant to the pending Department of Interior and Related Agencies Appropriations Act, the Department commenced planning for the sale of up to 7 million barrels of Weeks Island sour crude oil in order to obtain $\$ 100$ million in proceeds to fund the decommissioning of the Weeks Island site and other Reserve facilities requirements. Subsequently, on January 26,1996, the Balanced Budget Downpayment Act was enacted which, in part, authorized the sale.

On January 29, 1996, the Department of Defense's Defense Fuel Supply Center, acting as the Reserve's contracting agent for this non-emergency oil sale, issued a solicitation for competitive offers to purchase the crude oil. Offers are due February 20 and, assuming receipt of offered prices at reasonable prices, contracts are expected to be awarded on or about February 28. As necessary, additional offers will be sought thereafter on a 1 to 2 week basis.

The oil is available for delivery at the Department's St James Terminal and adjacent commercial pipeline systems. Following each delivery, the purchaser will be invoiced and payment will be made to the SPR Petroleum Account for subsequent use by the Reserve.

\section{PROPOSAL TO STORE FOREIGN-OWNED OLL IN THE RESERVE}

The Department of Energy is pursuing an initiative to store foreign-owned oil in the Strategic Petroleum Reserves. Following the transfer of Weeks Island oil to other sites, the Strategic Petroleum Reserve will have approximately 80 million barrels of available and usable capacity. The Department proposes to store foreign-owned oil in underutilized SPR caverns through a mutually beneficial agreement with another stockpiling country. In addition to generating revenues for the United States, such an arrangement could prove advantageous both to other stockpiling nations and the U.S. by: providing economical storage to other countries, promoting global stockpiling, and preserving storage caverns for future use.

The Strategic Petroleum Reserve has capacity to store 60 to 80 million barrels of foreign stocks on a segregated or commingled basis. On August 22, 1995, a State Department making the proposal was sent to all International Energy Agency (IEA) countries and candidates for IEA membership. To exempt foreign oil from customs duties and taxes, the Department is applying to have Foreign Trade Zone status extend to several sites. The Department will continue its discussion and negotiations with interest countries in 1996. 


\section{APPENDICES}

A. Strategic Petroleum Reserve Site Status

B. Strategic Petroleum Reserve Crude Oil Specifications 


\section{APPENDIX $A$ \\ Strategic Petroleum Reserve Site Status}

\section{BAYOU CHOCTAW}

\section{LOCATION}

Iberville Parish, Louisiana (12 miles southwest of Baton Rouge, Louisiana).

\section{ACQUISITION}

Acquired 355.95 acres fee simple, by condemnation April 1977, from numerous private owners. Union Texas Petroleum (a subsidiary of Allied Corporation) was the previous operator.

In 1985 the Department of Energy acquired an additional existing cavern through a cavern exchange agreement with Union Texas Petroleum. The transaction involved a 3.5 acre exchange with no net change in Government-owned acreage.

\section{ENVIRONMENTAL/PERMITS}

Environmental Impact Statement published December 1976; supplement published May 1977.

Four major Federal and State permits related to pipeline, well pad, storage, and storm water runoff acquired in 1978, and updated in 1980 and 1981.

\section{SITE DESCRIPTION}

A 75-million-barrel storage facility consisting of 65 million barrels in five existing caverns, plus 10 million barrels of storage capacity in a new Strategic Petroleum Reserve-developed cavern.

Oil, brine, and raw water piping distribution system connecting caverns with central plant, a water intake structure, 12 brine disposal wells located 2.5 miles offsite, and a pipeline for supplying brine to Union Texas Petroleum, Inc. Oil and water distribution system consists of over 50,000 feet of piping and 16 pumps totaling 22,000 horsepower. A 100,000 barrel brine pond and an oil/brine separator are also onsite.

Numerous permanent specialized buildings include: Control Center, Administration Building, Security Operations Center, Maintenance Shop and Laboratory, Electrical Switch Gear (5KV), 
Spare Parts Warehouse, Foam Storage, Instrument Shop, Documentation Storage and a Guard House.

\section{SYSTEM PARAMETERS}

Oil fill via 36-inch-diameter, 37.2-mile pipeline from St. James Terminal. Sustained system rate

- 110,000 bbl/d (brine disposal-constrained).

Raw water design pumping rate $-514,000 \mathrm{bbl} / \mathrm{d}$.

Brine disposal design pumping rate $-110,000 \mathrm{bbl} / \mathrm{d}$.

\section{DRAWDOWN}

Drawdown via 36-inch-diameter, 37.2-mile pipeline to St. James Terminal and to Capline pipeline.

Design drawdown capability $-480,000 \mathrm{bbl} / \mathrm{d}$.

\section{MAJOR ACCOMPLISHMENTS}

Repositioned 5 million barrels of crude inventory to accommodate transfer of Weeks Island crude to the Bayou Choctaw site.

Initiated receipt and storage of crude oil transferred from the Weeks Island site

Completed installation and performance testing of crude oil heat exchangers

Replaced deteriorated sections of on-site piping.

Completed internal lining of raw water and brine headers.

Completed internal lining of the brine pipeline to disposal wells.

Initiated the construction of electrical cable trays and duct bank system. 


\section{WEEKS ISLAND}

\section{LOCATION}

Iberia Parish, Louisiana (95 miles southwest of New Orleans).

\section{ACQUISITION}

Acquired 382.92 acres fee simple subsurface and 6.63 acres fee simple surface, by condemnation September 1977, from Morton Salt Company.

\section{ENVIRONMENTAL/PERMITS}

Environmental Impact Statement published January 1977; supplement published August 1977.

Major Federal permit related to oil pipeline to St. James Terminal acquired in 1978. Three major Federal and State permits related to oil storage, air emissions and storm water, and treated sewage effluent discharge acquired in 1979; EPA National Pollutant Discharge Elimination System permit updated in 1982.

\section{SITE DESCRIPTION}

Conventional room and pillar salt mine containing 70 million barrels of storage capacity in two levels. Dedicated to sour crude oil storage.

Oil piping distribution system consists of 11 (10 operational and one reserve) submersible electric pumps in the mine to boost crude to the surface and twin main-line pumps (plus one reserve) to deliver crude to the St. James, Louisiana Terminal during drawdown. Pumps total 17,000 horsepower. Firewater system has a 500,000 gallon tank with pumps, and mine inert gas and vapor recovery systems provide for safety.

Numerous permanent specialized buildings include: Administration and Maintenance, Control Center, Security Operations Center, Spare Parts Warehouse, Electrical Substation, Laboratory and Sample, Inert Gas Generator, Foam Storage, Fire Water Pump House, Mainline Pump House, Production Shaft Headframe, Production Shaft Hoist, Service Shaft Headframe, Service Shaft Hoist, Service Shaft Motor Control Center, and a Guard House. 


\section{SYSTEM PARAMETERS}

Oil fill via 36-inch-diameter, 67.2 mile pipeline from St. James Terminal. Sustained system rate - 350,000 bbl/d (terminal throughput limited).

\section{DRAWDOWN}

Drawdown via 36-inch-diameter 67.2-mile pipeline to St. James Terminal and to Capline pipeline.

Design drawdown capability - 590,000 bbl/d.

\section{MAJOR ACCOMPLISHMENTS}

Completed construction of an underground freeze wall surrounding the sinkhole to control ground water inflow during oil drawdown.

Commenced the transfer of Weeks Island inventory to Bayou Choctaw and Big Hill storage sites.

Conducted public hearings to gather inputs from the members of the community and industry on potential future site uses and on environmental issues to consider in the proposed decommissioning of the Weeks Island site.

Completed Environmental Assessment for decommissioning the Strategic Petroleum Reserve Weeks Island storage facility. 


\section{BRYAN MOUND}

\section{LOCATION}

Brazoria County, Texas (three miles southwest of Freeport, Texas).

\section{ACQUISITION}

Acquired 499.47 acres fee simple, by condemnation April 1977, from Freeport Mineral Company and other owners. Dow Chemical Company was the previous operator.

In 1986 Department of Energy acquired the pre-existing Brazoria County Road 242 within the site boundary through a relocation agreement with the county.

\section{ENVIRONMENTAL/PeRMITS}

Environmental Impact Statement published January 1977; supplement published December 1977. Phase III supplement published October 1981.

Five major Federal and State permits related to pipelines, water intake, and storage acquired in 1977 and 1978. National Pollution Discharge Elimination System updated 1981; renewed 1984. Seaway Environmental Impact Statement published June 1978. Supplement published October 1981.

Two major Federal permits related to brine disposal pipeline issued in 1978. Permit for brine discharge increased to 1.1 million bbl/d August 1981.

\section{SITE DESCRIPTION}

226-million-barrel storage facility consisting of 66 million barrels of capacity in four caverns existing upon site acquisition, plus 160 million barrels of storage capacity in 16 Strategic Petroleum Reserve-developed caverns.

36-inch-diameter, 14.6-mile brine disposal pipeline extending 13 miles offshore in the Gulf of Mexico.

Oil, brine and raw water piping distribution system connecting caverns with central plant and water intake structure located on Brazos River and connected by a 36-inch pipeline. Oil/brine/ water distribution system consists of over 101,000 feet of piping and 33 pumps totaling over 43,000 horsepower. Four 200,000-barrel oil storage tanks, two brine ponds $(15,000$ and $150,000)$, and an oil-brine separator. 
Numerous permanent specialized buildups include: Control Center, Administration Building, Security Operations Center, Maintenance, Spare Parts Warehouse, Foam Generator, Foam Storage (3), Electrical Switch Gear, and a Guard House.

\section{SYSTEM PARAMETERS}

Fill via 30-inch-diameter, 3.6-mile pipeline from Phillips Freeport Marine Terminal. Design oil fill rate $-240,000 \mathrm{bbl} / \mathrm{d}$. Sustained system rate $-180,000 \mathrm{bbl} / \mathrm{d}$.

Raw water design pumping rate $-1,355,000 \mathrm{bbl} / \mathrm{d}$.

Brine disposal design pumping rate $-980,000 \mathrm{bbl} / \mathrm{d}$ (permit limitation - 1,100,000 bbl/d).

\section{DRAWDOWN}

Drawdown via 30-inch diameter, 3.6 mile pipeline, to Phillips Freeport Marine Terminal.

Drawdown via 40-inch diameter, 46-mile pipeline to ARCO Pipeline Company's Texas City Pipeline Terminal and Docks.

Design drawdown capability $-1,250,000 \mathrm{bbl} / \mathrm{d}$.

\section{MAJOR ACCOMPLISHMENTS}

Completed degasification of approximately 11.4 million barrels of crude oil.

Installed 20 heat exchangers for cooling crude oil during drawdown.

Completed construction of new 24-inch brine disposal pipeline to the Gulf of Mexico.

Initiated major construction under the Life Extension Program, including a new distributed control system, new piping and instrumentation in cavern areas, and reconfiguration of site pipe racks. 


\section{WEST HACKBERRY}

\section{LOCATION}

Cameron Parish, Louisiana (22 miles southwest of Lake Charles, Louisiana).

\section{ACQUISITION}

Acquired 405.36 acres fee simple, by condemnation April 1977, from numerous private landowners. Olin Corporation was the previous site operator.

Acquired 160.0 additional acres fee simple by condemnation in two actions, July 1979 and March 1980.

\section{ENVIRONMENTAL/PERMITS}

Environmental Impact Statement published January 1977; supplement published April 1977. Phase III supplement published October 1981.

Six major Federal and State permits related to pipelines, drilling pads, water intake, and storage acquired in 1977 and 1978; National Pollutant Discharge Elimination System permit renewed 1984.

Texoma Environmental Impact Statement published November 1978; supplement published in October 1981.

Two major Federal permits related to a brine pipeline acquired in 1980 .

\section{SITE DESCRIPTION}

219-million-barrel storage facility consisting of 49 million barrels in five caverns existing upon site acquisition, plus 170 million barrels of storage capacity in 17 Strategic Petroleum Reservedeveloped caverns.

Oil, brine, and raw water piping distribution system connecting caverns with central plant, water intake structure located on Intracoastal waterway connected by a 42 -inch diameter, 4.5 mile pipeline, and 10 brine disposal wells. Consists of over 160,000 feet of piping and 45 pumps totaling over 82,000 horsepower. Brine disposal is via injection wells due to the decommissioning of the 27 mile brine line to the Gulf, a 175,000-barrel brine pond and an oilbrine separator. 
Numerous permanent specialized buildings include: Control Center, Administration Building, Security Operations Center, Maintenance, Spare Parts Warehouse, Covered Lay-Down, Film Storage, Foam Storage, and a Guard House.

\section{SYSTEM PARAMETERS}

Fill via 42-inch diameter, 42.8-mile pipeline from Sun Terminal, Nederland, Texas. Design oil fill rate $-225,000 \mathrm{bbl} / \mathrm{d}$. Sustained system rate $-175,000 \mathrm{bbl} / \mathrm{d}$.

Raw water design pumping rate $-1,450,000 \mathrm{bbl} / \mathrm{d}$.

Brine disposal design pumping rate $-900,000 \mathrm{bbl} / \mathrm{d}$

\section{DRAWDOWN}

Drawdown via a Department of Energy 42-inch-diameter, 42.8-mile pipeline to Sun Terminal, Nederland, Texas.

Drawdown via a 36-inch diameter, 12-mile oil pipeline (Department of Energy Lake Charles Pipeline) connecting to the Texas 22-inch common carrier pipeline and to refineries in Lake Charles, Louisiana.

Design drawdown capability $-1,250,000 \mathrm{bbl} / \mathrm{d}$.

\section{MAJOR ACCOMPLISHMENTS}

Completed degasification of approximately 19 million barrels of crude oil.

Installed six heat exchangers for cooling crude oil during drawdown.

Completed internal lining of brine pipeline to disposal wells.

Initiated major construction under the Life Extension Program, including a new distributed control system, new piping and instrumentation in cavern areas, and reconfiguration of site pipe racks. 


\section{BIG HILL}

\section{LOCATION}

Jefferson County, Texas (20 miles southwest of Beaumont, Texas).

\section{ACQUISITION}

Acquired 271 acres fee simple, by condemnation November 1982 and July 1983, from three landowners, i.e., 238.48 acres from Amoco, 27.06 acres from the Pipkin estate, and 5.46 acres from the Patrick Henry Phelan estate.

\section{ENVIRONMENTAL/PERMITS}

Environmental Impact Statement published October 1981.

State permits for drilling, underground hydrocarbon storage, pipeline operations, air quality, water appropriation, and water quality certifications were acquired in 1983. The EPA National Pollutant Discharge Elimination System permit was acquired in 1984.

\section{SITE DESCRIPTION}

160-million-barrel storage facility consisting of fourteen Strategic Petroleum Reserve-developed 11.5-million-barrel storage caverns.

Oil, brine, and raw water systems connecting caverns with central plant, water intake structure located on the Intracoastal Waterway connected by a 48-inch diameter, and brine disposal pipeline extending 3 miles offshore in the Gulf of Mexico. Oil and water distribution system consists of over 29 miles of piping and 15 pumps totaling 32,000 horsepower. 
Numerous permanent specialized buildings include: Control Center, Administration, Security Operations Center, Communications, Guard House, Covered Lay-Down, Fire House, Sample Storage, and Maintenance.

\section{SYSTEM PARAMETERS}

Fill via 36-inch-diameter, 25 mile pipeline from Sun Terminal, Nederland, Texas. Sustained system rate $280,000 \mathrm{bbl} / \mathrm{d}$.

Raw water design pumping rate $-1,400,000 \mathrm{bbl} / \mathrm{d}$.

Brine disposal design pumping rate $-1,400,000 \mathrm{bbl} / \mathrm{d}$ (permit limitation of $1,700,000 \mathrm{bbl} / \mathrm{d}$ ).

\section{DRAWDOWN}

Drawdown via 36 -inch-diameter, 25 mile pipeline to Sun Terminal, Nederland, Texas.

Design Drawdown capability - 930,000 bbl/d.

\section{MAJOR ACCOMPLISHMENTS}

Repositioned 6.9 million barrels of crude inventory to accommodate transfer of Weeks Island crude to the Big Hill site.

Initiated receipt and storage of crude oil transferred from the Weeks Island site

Completed construction and certification of potable water service line from Winnie, Texas

Awarded contract for new flow control valves to be installed under the Life Extension Program. 


\section{ST. JAMES TERMINAL}

\section{LOCATION}

St. James Parish, Louisiana (45 miles southeast of Baton Rouge, Louisiana, on the Mississippi River).

\section{ACQUISITION}

Acquired 104.76 acres of fee simple for terminal by condemnation in May 1978.

Acquired 47.68 acres fee simple for docks by condemnation in July 1978 .

\section{ENVIRONMENTAL/PERMITS}

St. James' Terminal Environmental Impact Statement is a component of the Bayou Choctaw supplement, published May 1977, and the Weeks Island supplement, published August 1977.

Two major Federal and State permits related to dock construction were acquired in 1978. Environmental Protection Agency discharge permit for storm water and sewage acquired in 1980. Dock Construction Permit modified 1982.

\section{SITE DESCRIPTION}

Terminal facilities include six storage tanks totaling two million barrels of capacity, tie-ins to Bayou Choctaw and Weeks Island sites, and to LOCAP and Capline pipeline terminals.

Oil distribution piping system connecting docks, tanks, and pump station consists of over 35,000 feet of piping and five pumps totaling over 7,500 horsepower, metering systems, and maintenance and control buildings.

Two docks with one berth each, able to accommodate vessels of up to 123,000 long tons maximum loaded displacement. A 42-inch-diameter pipeline connects the docks to the storage tanks.

\section{SYSTEM PARAMETERS}

Tanker unloading - design unloading capacity of $40,000 \mathrm{bbl} / \mathrm{hr}$.

Fill capabilities from terminal to: 
Bayou Choctaw: design pumping rate $-240,000 \mathrm{bbl} / \mathrm{d}$.

Weeks Island: design pumping rate $-480,000 \mathrm{bbl} / \mathrm{d}$.

Terminal sustained system fill rate: $350,000 \mathrm{bbl} / \mathrm{d}$.

\section{DRAWDOWN}

Crude oil from Bayou Choctaw and/or Weeks Island to be distributed across docks and to LOCAP and Capline Pipeline Terminal.

SUSTAINED TANKER LOADING RATE: $435,000 \mathrm{bbl} / \mathrm{d}$.

MAJOR ACCOMPLISHMENTS

Completed the cleaning and inspection of two 400,000-barrel oil storage tanks. 


\section{APPENDLX B \\ Strategic Petroleum Reserve Crude Oil Specifications}

\begin{tabular}{|c|c|c|c|}
\hline Characteristic & Sour & Sweet ${ }^{\mathrm{c}}$ & $\begin{array}{l}\text { Primary ASTM } \\
\text { Test Method }\end{array}$ \\
\hline API Gravity $\left[{ }^{\circ} \mathrm{API}\right]$ & $30-45$ & $30-45$ & D 1298 \\
\hline Total Sulfur [Wt.\%], Max. & 1.99 & 0.50 & D 1552 \\
\hline Pour Point $\left[{ }^{\circ} \mathrm{F}\left({ }^{\circ} \mathrm{C}\right)\right]$, Max. & $50(10)$ & $50(10)$ & D 97 \\
\hline Salt Content [Lbs. $/ 1,000$ Bbls.], Max. & 50 & 50 & D 3230 \\
\hline $\begin{array}{l}\text { Viscosity } \\
\left.\text { [SUS @ } 60^{\circ} \mathrm{F}\left(\mathrm{cSt} @ 15.6^{\circ} \mathrm{c}\right)\right] \text {, } \\
\text { Max. } \\
\text { [SUS @ } 100^{\circ} \mathrm{F}(\mathrm{cSt} @ \\
\left.\left.37.8^{\circ} \mathrm{C}\right)\right], \mathrm{Max} .\end{array}$ & $\begin{array}{l}150(32) \\
70(13)\end{array}$ & $\begin{array}{l}150(32) \\
70(13)\end{array}$ & D $445 \&$ D 2161 \\
\hline $\begin{array}{l}\text { Reid Vapor Pressure [Psia @ } 100^{\circ} \mathrm{F} \\
\left.\left(\mathrm{kPa} @ 37.8^{\circ} \mathrm{C}\right)\right], \mathrm{Max}\end{array}$ & $11(76)$ & $11(76)$ & D 323 \\
\hline $\begin{array}{l}\text { Total Acid Number [mg KOH/g], } \\
\text { Max. }\end{array}$ & 0.40 & 0.40 & D 664 \\
\hline Water and Sediment [Vol. \%], Max. & 1.0 & 1.0 & $\begin{array}{c}\text { D } 473 \& \\
\text { D } 4006 \text { or D } 4928\end{array}$ \\
\hline
\end{tabular}




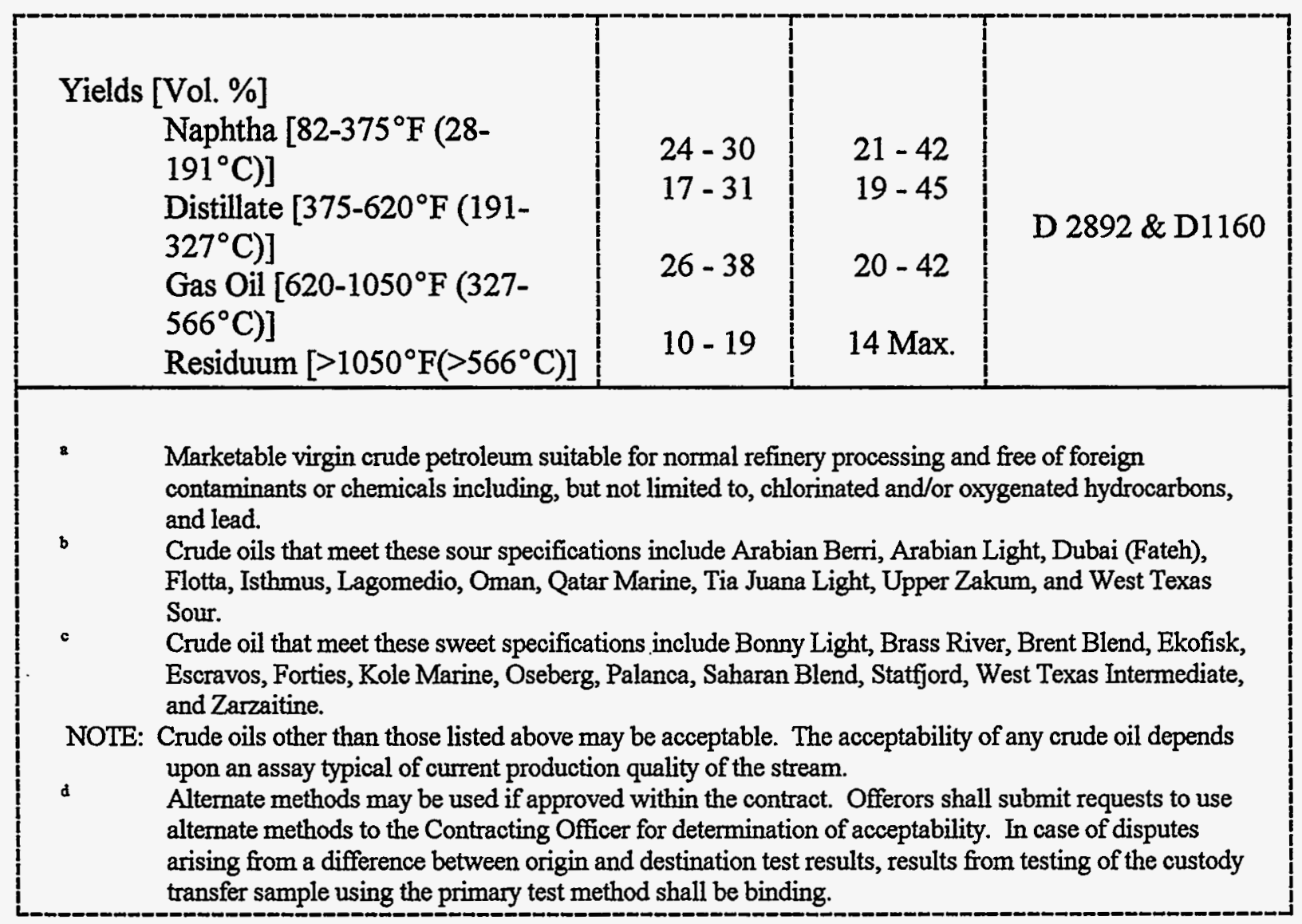

